\title{
Asset allocation and monetary policy: Evidence from the eurozone*
}

\author{
Harald Hau ${ }^{\mathrm{a}, *}$, Sandy Lai ${ }^{\mathrm{b}}$ \\ ${ }^{a}$ University of Geneva, Swiss Finance Institute, and CEPR, \\ Geneva Finance Reserach Institute, 42 Boulevard du Pont d'Arve, 1211 Geneva, Switzerland \\ ${ }^{\mathrm{b}}$ Faculty of Business and Economics, University of Hong Kong, \\ K.K. Leung Building, Pokfulam Road, Hong Kong
}

November 1, 2015

\begin{abstract}
The eurozone has a single short-term nominal interest rate, but monetary policy conditions measured by real short-term interest rates varied substantially across countries in the period 2003-2010. We use this cross-country variation in the (local) tightness of monetary policy to examine its influence on equity and money market flows. In line with a powerful risk-shifting channel, we find that fund investors in countries with decreased real interest rates shift their portfolio investment out of the money market and into the riskier equity market, causing significant equity price inflation in countries where investment home bias is the strongest.
\end{abstract}

JEL classification: G11, G14, G23

Keywords: Monetary policy, Asset price inflation, Risk-shifting, Taylor rule residuals

\footnotetext{
* We thank the referee Stephan Siegel for valuable suggestions as well as Geert Bekaert, Pasquale Della Corte, Matthias Efing, Mathias Hoffmann, Yi Huang, Alexander Ljungqvist, Gustavo Manso, Tao Shu, Stefan Sperlich, John Taylor, Cedric Tille, Wei Xiong. We also thank seminar and conference participants at the Chinese University of Hong Kong, the 2013 European Economics Association Annual Meeting, the 2013 European Finance Association Meeting, the Graduate Institute of International and Development Studies, the Hanqing Institute at Renmin University (Peking, China), the Hong Kong Institute for Monetary Research and Hong Kong University of Science and Technology Joint Conference on Macroeconomics and International Finance, the London Business School, the 2013 Sciences Po Workshop on Empirical Monetary Economics, the 2013 Swiss National Bank and University of Zürich Workshop on Asset Prices and Exchange Rates, and the Swiss National Bank for their feedback. The research project benefited from a Sinergia Research Grant from the Swiss National Science Foundation and support from the Hong Institute for Monetary Research.

${ }^{*}$ Corresponding author. Tel.: +41 22379 9581. fax: +41 223799727

E-mail addresses: prof@haraldhau.com (H. Hau), sandy_lai@hku.hk (S. Lai)
} 


\section{Introduction}

Following the worst financial crisis (2007-2009) since the Great Depression, a controversial debate has focused on the role of monetary policy for asset price inflation and financial risk taking in general. Critiques of US monetary policy have asserted a powerful risk-taking channel whereby excessively low monetary policy rates induce more risky asset allocations by various economic agents (Rajan, 2006; Adrian and Shin, 2010; Borio and Zhu, 2012). Households, as well as financial intermediaries, could seek higher risk in search of higher yields, and such return chasing can impact leverage and asset prices (Rajan, 2006; Taylor, 2008; Gambacorta, 2009; De Nicolò, Dell'Ariccia, Laeven, and Valencia, 2010). The exceptionally low (and even negative) real short-term interest rate in the current post-crisis environment raises the concern that leverage adjustment is delayed and asset risk allocations are distorted again.

The idea that low real rates for credit can trigger an expansion of leverage accompanied by an asset price boom has a long economic history dating back to Kurt Wicksell (1898). ${ }^{1}$ Low real interest rates for riskless investments can entice investors to seek more risky investment positions. The risk-taking channel could operate through increased opportunity costs to investment in low return assets, lower investor risk aversion in periods of low real rates, or less stringent funding conditions for leveraged investments.

Empirically, evaluating the effect of monetary policy on investor behavior faces two types of endogeneity issues. First, the nominal rate setting by a monetary policy authority is a function of business cycle conditions. Such an endogenous nominal rate-setting process makes it difficult to determine whether investors react to the nominal rate change itself or to the business cycle condition. Second, given that local (or national) business cycles can exert influence on local inflation (and, hence, the local real short rate), any evidence of an association between investor equity flows and the real short rate can be a manifestation of both driven by local business

\footnotetext{
${ }^{1}$ Hellwig (2011) suggests that such Wicksellian dynamics represent a salient feature of southern Europe's recent boom and bust cycle.
} 
cycles.

This paper seeks to address both endogeneity challenges. To deal with the endogenous nominal rate setting, we focus on the eurozone. We use the monetary policy process in the eurozone, with its different national real short-term interest rates, to identify how geographic variation in monetary policy conditions affects investors' asset allocations to equity and money market funds. ${ }^{2}$ In a currency union, the central bank is constrained to set only one single shortterm nominal interest rate for the entire currency area. Therefore, the endogeneity concern is greatly mitigated in our study because we focus on deviations of local monetary policy conditions from eurozone averages (namely, deviations of national real short-term interest rates from eurozone averages). This allows us to explore investors' investment allocations as a reaction to unintended geographical monetary policy variations. For example, the European Central Bank (ECB) is unlikely to adjust its short-term nominal interest rate just because Spain experiences a higher inflation rate relative to the eurozone average, implying that the nominal rate setting is no longer a function of the local business cycle as it would be under the rate setting by an autonomous Spanish central bank. The difference between the Spanish real interest rate and the eurozone average is (by construction) orthogonal to the ECB nominal rate-setting process. ${ }^{3}$

The second endogeneity issue concerns the local inflationary component of the real rate. Even though the nominal rates are set in Frankfurt, Germany, based on euro area aggregates, the Spanish inflation rate itself is affected (or even driven) by the Spanish business cycle. Therefore, any correlation between Spanish fund investors' risk shifting into equity and a lower Spanish real rate could be a result of changes in aggregate demand (income channel) or higher expected

\footnotetext{
${ }^{2} \mathrm{~A}$ well-documented strong investor bias toward nationally distributed investment funds [see, e.g., the survey paper by Sercu and Vanpee (2007)] allows us to link local relative monetary conditions to fund-level inflows and outflows in the equity and money markets of different eurozone countries.

${ }^{3}$ We also verify that the ECB's nominal rate-setting process does not affect the future real short rate $S R$ asymmetrically across countries in a way that depends on their current real short rates. We regress the local inflation changes $\left(\Delta I N F_{c, t}\right)$ for each country $c$ at quarter $t$ on lagged euro overnight interest rate changes $\left(\triangle E O N I A_{t-k}\right)$, the real short rate $\left(S R_{c, t-k}\right)$, and $\Delta E O N I A_{t-k} \times S R_{c, t-k}$ in the past one to four quarters $(k=1,2,3,4)$, as well as the country fixed effects. We find no evidence that any of the interaction term $\triangle E O N I A_{t-k} \times S R_{c, t-k}$ is statistically significant.
} 
local firm cash flows (cash flow channel) in Spain affecting both investor asset allocation and the inflation rate, rather than a result of investor risk shifting in response to the low real rate itself (risk-taking channel). We employ three empirical strategies to distinguish the risk-taking channel from the two alternative channels.

First, we use control variables that proxy for contemporaneous changes in local aggregate output, output gap, credit growth, value-added tax, and return on assets of local firms to explore whether these variables attenuate the correlation between local real rate changes and local equity fund flows. These income and corporate cash flow measures should represent better proxies for the contemporaneous business cycle than the real short rate because inflation (and, thus, the real rate) typically features a more sluggish response to business conditions (due to nominal price stickiness). Inclusion of such control variables in the regression should attenuate the estimated fund flow effect of the real rate if the income and cash flow channels matter much for fund flows. Yet, we find no evidence that these control variables have any significant explanatory power for equity fund flows, whereas the real rate change retains its explanatory power.

Second, under nominal price stickiness and inflation persistence (Álvarez, Dhyne, Hoeberichts, Kwapil, Bihan, Lünnemann, Martins, Sabbatini, Stahl, Vermeulen, and Vilmunen, 2006; Andersson, Masuch, and Schiffbauer, 2009), we can instrument the real rate change with its lagged values, thereby restricting the direct influence of contemporaneous business cycle conditions on the estimated fund flow effect of the real rate. Third, we disaggregate equity funds into those with a local investment focus and those with a foreign investment focus. The latter consists of funds that invest more than half their fund assets in foreign stocks. Such fund flows should not be driven by time-varying cash flow expectations related to local business cycles but rather by business cycles in the foreign investment destination. However, we find that equity fund flows with a foreign investment destination react to the local real rate variations as strongly as flows of funds with a purely domestic investment focus. Taken together, the 
evidence suggests that investor risk shifting toward more leveraged equity positions does occur in reaction to changes in the local real rate.

Constrained by data availability, our analysis focuses on investor flows into mutual funds during the period 2003-2010. ${ }^{4}$ Such investor fund flows have a dual interpretation as a measure of investor asset substitution and revealed investment and risk preferences. In equilibrium, market clearing implies that net purchases of stocks by local fund investors need to be balanced by corresponding net sales by other local investors or foreign stock investors. Because foreign investors have a different consumption basket, they might not be subject to changes in the local inflation rate and real rate and, therefore, (ceteris paribus) are likely to accommodate asset demand changes from local investors. In this case, local equity fund inflows can crowd out foreign equity investment and increase equity home bias by local investors. Although our sample is constrained to investor flows to mutual funds, we do find evidence that the local equity mutual fund flows for the eight eurozone countries we use in our sample show a significantly negative correlation with the respective net foreign equity flows of the US, consistent with the argument that local fund flows trigger an international asset substitution effect, at least as far as US investors are concerned. ${ }^{5}$

The second and more important interpretation of local fund flows is based on an argument of revealed preference change. Fund inflows are akin to market orders in the market microstructure literature because they represent an investment order for a fixed quantity to be executed (or invested) at an uncertain future price. For example, any buy order is the result of either an increase in the investor's asset valuation or a decrease in the expected execution price. Because correlated buy orders by a large investor group can be expected to raise the execution price, any aggregate fund investor inflows need to reflect an even greater change in the equity valuation

\footnotetext{
${ }^{4}$ Data on other types of money flow in the eurozone (such as hedge fund flows or investment flows for other institutional investors) provide relatively low coverage during our sample period. In light of the data quality concern, we focus on mutual fund flows only.

${ }^{5}$ Subsection 4.3 provides a more detailed discussion of this issue.
} 
by this investor group.

We undertake our empirical analysis at the aggregate country level because our variable of interest, the real interest rate, varies only at the country level. Aggregation of fund flow data attenuates flow heterogeneity at the fund level and reduces the role of small funds with their more idiosyncratic fund flow patterns. ${ }^{6}$ Our results show that loose monetary policy conditions measured by the decrease in the real short rate correlate strongly with the crosssectional differences in equity fund inflows and money market fund outflows. A decrease of 10 basis points in the real short-term interest rate is associated with a $1 \%$ incremental equity fund inflow relative to fund assets and a $0.8 \%$ incremental outflow from money market funds.

While fund flow evidence out of money market funds and into equity funds captures an increased risk appetite of a broad investor segment, financial stability concerns the asset price impact of such asset reallocation. We therefore estimate the stock price dynamics triggered by differences in monetary policy conditions in the eurozone using our identification of equity flows related to monetary policy. Accommodating local monetary policy conditions can inflate local equity prices through a lower risk-free real rate, a change in the local risk premia if assets are at least partially subject to local asset pricing, and a price pressure effect caused by increased equity demand if the asset supply is price inelastic in the short run. Our analysis focuses on the last two channels by defining for each country a benchmark group of the $20 \%$ stocks with the lowest fund holdings over the past three years [Low Fund Holding Index (LFHI)]. Equity fund returns are measured relative to the returns of this benchmark group and, therefore, capture the differences in price pressure or exposure to changing local risk premia between investable stocks in the fund portfolios and the benchmark low-investability LFHI stocks.

The relative equity fund returns in each country do react positively to local portfolio shifts toward equity triggered by changes in local monetary policy conditions. The measured excess

\footnotetext{
${ }^{6}$ Nevertheless, we reproduce our results using fund-level regressions and confirm that the coefficients obtained are very similar to those of the aggregate fund flow regressions.
} 
return is approximately $2 \%$ for a 10 basis point decrease in the local real interest rate if all countries are weighted equally. If countries are weighted by the local investment share of domestic institutional investors relative to the local stock market capitalization, we find a much stronger excess return effect of roughly $4 \%$, suggesting that the excess return is strongest in countries where local institutional investors are important.

We conduct a number of robustness tests. First, we explore the role of household inflation expectations for the risk-taking channel based on the European Commission's Consumer Survey data. As highlighted by Arnold and Lemmen (2008), collective inflation expectations differ from the best statistical forecast of realized inflation and could represent the more relevant explanatory variable if real investment returns are a key determinant of household risk allocations. In line with this interpretation, we find that after the substitution of the realized real rate changes with the expected real rate changes (calibrated to household inflation expectations), the economic and statistical significance of the real rate effect increases for both equity and money market flows. Second, we conduct a subsample analysis on the precrisis period of 2003/q1-2007/q2 and find a qualitatively similar result to our full sample period (2003-2010), alleviating the concern that the recent financial crisis could taint our inferences. Third, we replace the real short rate with Taylor rule residuals as the proxy of local monetary policy conditions and again obtain qualitatively similar results.

Monetary policy is likely to encompass other dimensions than just the short-term rate setting process, such as communicating a long-term policy stance or influencing long-term inflation expectations. By focusing on the involuntary cross-sectional differences in the real short rates, we certainly miss any indirect transmission channels common to all countries in the currency union. From this perspective, our study provides a lower bound for the asset allocation effect of monetary policy operating specifically through local real short-term interest rates. Lastly, the contribution of this paper is to show a macroeconomically relevant investor portfolio shift and related equity price effect for monetary policy. We acknowledge that data constraints preclude 
us from distinguishing the three components (changes in opportunity costs to investment in low return assets, changes in investor risk aversion, and changes in funding conditions) of the risk-taking channel by retail investors. However, further study in this area is warranted, and we leave it for future research.

In the following section, we survey the related literature. In Section 3, we discuss the data. Evidence on the asset allocation effect of monetary policy is presented in Section 4. The stock price effect of real rate changes is explored in Section 5. We conclude in Section 6, with some remarks on prudential policies and the stability of a currency union.

\section{Related literature and policy issues}

The role of asset prices for monetary policy is a subject of considerable controversy. A precrisis consensus among many US policy makers was that asset price bubbles were either too hard to identify or beyond the control of monetary policy (Bernanke and Gertler, 1999, 2001; Bernanke, 2002; Kohn, 2006, 2008). An opposing camp argued that a central bank should pay attention to asset price inflation and possibly dampen speculative behavior by increasing interest rates (Borio, and Lowe, 2002; Cecchetti, Genberg, Lipsky, and Wadhwani, 2000). The latter view is predicated on an endogenous risk hypothesis, whereby investors or financial intermediaries seek more risk when real interest rates are low. This view has gained much policy support based on the recent crisis experience, although direct empirical evidence for it is still scarce. ${ }^{7}$ Yet, such evidence matters not only for the future design of monetary policy but also for gauging the extent to which monetary policy should account for the observed asset price inflation. The current study provides direct empirical evidence on this issue in a unique currency union setting.

The literature has explored a number of risk channels through which loose monetary policy can contribute to financial instability. First, recent evidence supports the view that lax

\footnotetext{
${ }^{7}$ See Issing (2009) for an account of the post-crisis changes in the monetary policy debate.
} 
monetary policy affects the riskiness of loans granted by banks (Ioannidou, Ongena, and Peydró, 2009; Maddaloni, and Peydró, 2011; Altunbas, Gambacorta, and Marquéz-Ibañez, 2014; Jiménez, Ongena, Peydró, and Saurina, 2014). Monetary policy could thus contribute to the buildup of credit risk and bank fragility. Second, low real interest rates could push financial intermediaries to expand their balance sheet and increase their financial risk through leverage (Adrian, and Shin, 2010). Our paper focuses on yet another group of investors: retail investors. We argue that these investors could seek more risk in their investment portfolios if low-risk investment provides insufficient returns and renders them less risk averse. A related study by Bekaert, Hoerova, and Lo Duca (2013) provides evidence that innovations to the real interest rate positively correlate with future changes in the Chicago Board Options Exchange Volatility Index (VIX). Such a delayed effect of real interest rates on investor risk aversion is consistent with the direct asset reallocation evidence we show in this paper: Real interest rate changes trigger investor preference changes toward fewer fixed income and more equity investments.

Previous monetary policy research has explored the relation between nominal rate changes and asset prices. Work by Thorbecke (1997), Rigobon and Sack (2004), Bernanke and Kuttner (2005), and Bjørnland and Leitemo (2009) all find that expansionary (contractionary) monetary policy affects stock prices positively (negatively). However, given that stock prices are a noisy and endogenous measure, any stock price effect alone is uninformative about the risk-taking channel of monetary policy. This paper focuses on local fund flows and their disaggregation by investment destination and, therefore, provides more direct evidence for a causal role the real rate plays in investor risk shifting. Our joint estimation of fund flows related to monetary policy and equity returns also provides a more precise inference of the asset price effect of monetary policy.

Our evidence is also consistent with a large finance literature on the asset price effects of portfolio shifts. For example, Goetzmann and Massa (2003) show how daily Standard \& Poor's (S\&P) 500 index returns correlate with contemporaneous index fund inflows. Index fund flows 
triggered by stock index inclusions or exclusions have been shown to have systematic, though mostly transitory, asset price effects (Chen, Noronha, and Singal, 2004). In our analysis, fund flows are not deemed exogenous. Instead, they are examined as a function of monetary policy conditions.

Methodologically, our study benefits from recent advances in the analysis of dynamic panels (Holtz-Eakin, Newey, and Rosen, 1988; Arellano and Bond, 1991; Arellano and Bover, 1995; Blundell and Bond, 1998). Equity fund flows feature a pronounced serial correlation. Therefore, we need to estimate a dynamic panel for which the ordinary least squares (OLS) or least squares dummy variable (LSDV) estimators are known to deliver inconsistent results, particularly if the time dimension of the panel is small. Our inference is based on the use of difference generalized method of moments (DGMM) and system generalized method of moments (SGMM) estimators, following the procedure suggested by Roodman (2009). The fund flow equation is estimated in (time) differences to purge country fixed effects. Lagged fund flows (along with any other similarly endogenous variables) are instrumented. The DGMM estimation uses lagged level variables as the instruments, and SGMM gains efficiency by adding a level equation estimated with differenced instruments. For SGMM, the consistency of the estimates relies on the orthogonality of the differenced instruments and the country fixed effects, rendering the SGMM estimator potentially more fragile. In most cases, we report results for both estimators.

\section{Data}

A strong home bias in the population of fund investors (who tend to invest in funds that are distributed and marketed locally) allows us to associate local investors' risk choices with inflows and outflows of locally distributed funds. Only investment funds managed in Belgium, Ireland, and Luxembourg appear to draw on a pan-European investor community and, therefore, are excluded. Greece is excluded because of the lack of fund flow data. Our final sample consists of eight eurozone countries: Austria, Finland, France, Germany, Italy, the Netherlands, Portugal, 
and Spain.

Our analysis is predicated on the existence of a single nominal rate throughout the eurozone during our sample period. Existing evidence suggests that secured overnight lending featured identical rates for our sample countries at least until the eruption of sovereign default risk in 2011 (Boissel, Derrien, Örs, and Thesmar, 2014) and possibly even through the peak of the crisis in 2011 if one focuses on repo transactions with high-quality collaterals (Mancini, Ranaldo, and Wrampelmeyer, 2014). We address the concern about the cross-sectional variation in the riskless nominal rate by restricting our sample to the period from 2003 to 2010. In addition, we verify that our results are robust to the exclusion of the three crisis countries (Italy, Portugal, and Spain) and alternatively to a shorter sample for the noncrisis period, 2003/q1-2007/q2 (discussed in Subsection 4.5).

Monetary research has typically inferred a country's monetary policy conditions from either the short-term real interest rate or the Taylor rule residuals. As both the real short rate and the Taylor rule residuals yield very similar results, we focus our analysis on the former and present the result of the latter in the robustness section (Subsection 4.5). We measure the quarterly local real short-term interest rate $S R$ by the difference between the average quarterly overnight interest rate (EONIA) and the local inflation rate. Real short rates are based on realized quarterly inflation, but investors' risk allocation decisions should respond to the expected real rate and expected inflation. Thus, we also derive inflation expectations from the European Commission's Consumer Survey data [see Arnold and Lemmen (2008) for details]. We calibrate the survey response of quarterly inflation expectations to the realized inflation and use the average household inflation forecast to derive the expected real short rate, $S R$ (expected), as described in Table A.1. The correlation between the real short rate and the expected real short rate is high, about 0.97 , over our sample period.

Table 1 reports the summary statistics. The average $S R(S R$ (expected)) is the lowest in Spain at $-0.096 \%(-0.046 \%)$ and highest in Finland at $0.22 \%(0.18 \%)$ over the 32 quarters 
of our sample period (2003-2010). Fig. 1 plots the time series of the real short rates and the expected real short rates in Panels A and B, respectively, and their changes in Panels C and D, respectively. Overall, monetary policy conditions show considerable independent cross-sectional variation in the eurozone. The average difference between the highest and lowest real interest rate across the eight sample countries is approximately 53 basis points. To measure the local policy conditions relative to the eurozone average in our subsequent analysis, we demean both the real short rate $S R$ and the expected real short rate $S R$ (expected) by subtracting from them the respective cross-sectional average rate over the eight sample countries.

The role of local institutional investors also differs across the eurozone countries. Bartram, Griffin, and $\mathrm{Ng}$ (2014) find that the average float-adjusted ownership of local institutional investors (reported to the FactSet database) in the quintile of firms with the largest market capitalization value varies from $1.1 \%$ for Austria to $10.7 \%$ for Germany over the period 20002009. We use this ownership share to proxy for the share of the local market held by local institutional investors (LocInstShare). We expect that the larger this share, the more likely it is that local equity fund inflows will lead to local asset price inflation.

Our fund flow data are from the Lipper fund database. Fund coverage in Lipper is relatively incomplete prior to 2003. For example, it accounts for only $1.2 \%, 2 \%$, and $3.3 \%$ of the entire mutual fund universe in, respectively, Austria, France, and Germany in 2002 but increases substantially to $60.3 \%, 68.4 \%$, and $95.7 \%$ by the end of $2003 .{ }^{8}$ Most funds report returns monthly, but some funds report their total net asset values only quarterly, especially in the early part of our sample period. Therefore, we focus our analysis on the quarterly data from the beginning of 2003 to the end of 2010 . Fig. 2 contrasts the total fund asset holding statistics reported by Lipper and those reported by the European Fund and Asset Management Association (EFAMA).

\footnotetext{
${ }^{8}$ The size of mutual fund industries in the eurozone is obtained from the European Fund and Asset Management Association (EFAMA). Some discrepancies exist in reporting conventions between EFAMA and Lipper. For example, EFAMA includes funds of funds in the reported statistics of some countries (including France and Italy), but Lipper does not.
} 
It shows that funds in the eight eurozone countries are generally well represented in the Lipper database, with more discernible coverage shortfall in equity funds for France and Spain and in money market funds for Austria, Italy, and the Netherlands. Such incomplete data coverage can attenuate to some extent the power of our identification mechanism for fund flows in these countries.

To get a cleaner measure of local retail investors' asset allocation reaction to monetary policy conditions, for each sample country we include only funds domiciled and marketed exclusively in the local market. Also, we exclude funds that are sold mainly to institutional investors. Table 2 reports summary statistics for the aggregate fund flows. ${ }^{9}$ Both fund flows and fund returns are measured in euro terms. Across the eurozone, investors generally withdrew capital from money market funds during our sample period. Germany and Portugal experienced the largest outflows, with a mean (median) of $-4.7 \%(-4.0 \%)$ and $-3.5 \%(-3.3 \%)$, respectively, per quarter. By contrast, investors directed capital into equity funds in Austria, Finland, and Portugal. During this period, equity funds registered a (fund size-weighted) aggregate mean return of $1.7 \%$ per quarter.

Construction of the value-weighted Low Fund Holding Index uses the semiannual portfolio holdings of worldwide funds from the Thompson Reuters International Fund database. The database is described in detail in Hau and Lai (2013). The $20 \%$ least held stocks constituting the LFHI index account for a very small percentage of semiannual holdings by mutual funds. Their aggregate fund holdings relative to shares outstanding range from $0.02 \%$ in Portugal to $0.15 \%$ in Finland. The average across all eight countries is only $0.07 \%$. Fig. 3 illustrates the $20 \%$ benchmark LFHI stocks and the remaining $80 \%$ of stocks by country in a scatter plot of percentage fund holdings and stock size. The figure shows that the benchmark stocks with extremely low fund holdings exist for a wide range of stock size. The pooled mean return (2.8\%)

\footnotetext{
${ }^{9}$ The total net asset values of money market funds are completely missing for Finland in 2004/q3 and for the Netherlands in 2002/q4. As a result, Finland has two missing observations for the aggregate money market flows, and the Netherlands has one.
} 
for the LFHI index is close to the return (2.3\%) for the MSCI country indices, MKT. We provide detailed definitions and data sources for the aforementioned variables in Table A.1.

\section{Asset allocation effect of monetary policy}

Next, we report the evidence for the relation between local monetary policy conditions across eurozone countries and mutual fund flows into locally distributed funds. First, we present the base results (Subsection 4.1) before we address endogeneity concerns in two different ways. We augment the regressions with local business cycle control variables (Subsection 4.2), and focus on the fund flow component with a foreign investment destinations (Subsection 4.3). Finally, we replace realized real rate changes with the expected real rate change based on consumer survey data (Subsection 4.4) and discuss other robustness issues (Subsection 4.5).

\subsection{Base results}

The serial correlation of fund flows requires us to include a lagged dependent variable in the model specification. A single lagged dependent variable proves sufficient to capture the flow dynamics. We also include lagged market returns $\left(M K T_{c, t-1}\right)$ in the specification because favorable market returns in a country can correlate with more aggregate equity fund inflows. The regression coefficient of particular interest is $\alpha_{1}$, which captures the contemporaneous effect of a country's short-term real interest rate changes $\left(\Delta S R_{c, t}\right)$ on new equity or money market investment. The specification allows for country fixed effects $\mu_{c}$ and purges time fixed effects by removing the cross-sectional mean from each variable in each quarter:

$$
\text { FundFlow }_{c, t}=\alpha_{1} \Delta S R_{c, t}+\alpha_{2} \text { FundFlow }_{c, t-1}+\alpha_{3} M K T_{c, t-1}+\mu_{c}+\epsilon_{c, t} .
$$

Table 3 presents the regression results for equity funds. Column 1 reports the LSDV estimator as a benchmark, which removes country fixed effects from the regression using the dummy variable approach. Even with the inclusion of country dummies, a short sample of 32 time 
series observations suggests that the coefficient estimates are likely to be biased, particularly for the lagged dependent variable. Intuitively, the estimated fixed effects might not fully capture country variations in the average fund flows so that the lagged dependent variable still features some correlation with the residuals, biasing $\alpha_{2}$ upward. ${ }^{10}$

An obvious specification concern is the endogeneity of the real interest rate changes $\Delta S R$ to the contemporaneous local business cycle, which can simultaneously influence investor fund allocation decisions and the local inflation rate. The role of the contemporaneous local business cycle effect can be reduced by instrumenting $\Delta S R$ and FundFlow with their own lagged values.

A regression based on the DGMM estimator allows for unbiased estimates with the lagged dependent variable, as well as for the instrumentation of covariates. Unlike LSDV, DGMM removes country fixed effects from the data through differencing. Again, we purge time fixed effects by removing the cross-sectional mean from each variable in each quarter. Columns 2 and 3 of Table 3 report the DGMM regression results using six and nine instruments, respectively. For $\Delta S R_{c, t}$ and $M K T_{c, t-1}$, we use their own lagged values in the past one to two quarters as instruments because they do not feature any autocorrelation at higher orders. For FundFlow we include lags 2-3 of the variable as instruments in Column 2 and lags 2-6 in Column $3 .^{11}$

A comparison of the LSDV estimates with the DGMM estimates shows a slightly smaller coefficient $\alpha_{2}$ for the latter. The autocorrelation in fund flows is approximately 0.3 based on the DGMM estimates. A bias-corrected version of the LSDV estimator (not reported) also provides estimates very similar to those in Column 1. However, the use of instruments in Columns 2 and

\footnotetext{
${ }^{10} \mathrm{In}$ light of the loss of degrees of freedom in our regressions with demeaned variables, we adjust all reported $t$-statistics downward through the division of square root of $(N T-k) /(N T-k-T)$, where $N, T$, and $k$ denote the number of cross-sectional observations, time periods, and independent variables, respectively.

${ }^{11}$ To address concerns about weak instruments for the real rate changes, we note that the coefficients $(t$ statistics $)$ in the first stage regression are $-0.77(t=-11.81)$ and $0.027(t=0.40)$, respectively, for lags 1 and 2 of the real short rate changes, $-0.002(t=-0.87)$ and $-0.002(t=-1.05)$ for the two lagged fund flow variables, and $0.0(t=0.79)$ and $0.0(t=0.0)$ for the two lagged market returns. The intercept of the regression is $0.0(t=0.05)$. The Cragg-Donald F-statistic for the regression is 34.79, rejecting the null hypothesis of weak instruments based on the $5 \%$ critical value (19.28) provided by Stock and Yogo (2005). The null hypothesis of weak instruments is also rejected for fund flows and stock market returns with the Cragg-Donald F-statistic of 23.61 and 65.12 , respectively.
} 
3 yields a much more negative coefficient estimate for the monetary policy variable. A decrease in the real short-term interest rate by 10 basis points predicts a quarterly equity fund inflow of about $1 \%$ of fund assets and a permanent inflow of about $1.4 \%$ [estimated by $\alpha_{1} /\left(1-\alpha_{2}\right)$ ] or about $€ 8.7$ billion in equity flows. These flow effects of monetary policy conditions are therefore statistically highly significant and economically large. If we assume that the flow effect is linear in the real rate changes, then a decrease of 1 percentage point in the real rate corresponds to a substantial $14 \%$ of permanent equity inflows relative to fund assets. By contrast, the lagged quarterly aggregate stock market returns, $M K T_{c, t-1}$, do not appear to explain equity fund flows. We also find that lagged short rate changes do not explain equity fund flows. Only the contemporaneously reacting investors produce a portfolio rebalancing effect that is statistically identifiable.

An alternative estimation procedure involves the SGMM estimator, which uses the level and difference equations and estimates both simultaneously. Given the moderate autocorrelation of the lagged flow variable, the SGMM procedure is likely to yield only modest efficiency gains over the DGMM procedure. Moreover, such efficiency gains are achieved only if additional orthogonality conditions for country fixed effects are met (Roodman, 2009). ${ }^{12}$ In the interest of a robust inference, we focus our discussions on the DGMM estimates but report the SGMM results nevertheless in Columns 4-5 using the same instruments used for DGMM1 and DGMM2 in Columns 2-3. The $\Delta S R_{c, t}$ estimates under SGMM are very similar, but at a slightly higher significance level. The Hansen test does not reject the validity of the (over-) identification conditions in any of the specifications. ${ }^{13}$

Generally, equity flows can also be influenced by the level of the real interest rate, which can influence saving or consumption decisions. Our empirical framework does not account for

\footnotetext{
${ }^{12}$ The orthogonality conditions require aggregate country fund flows to be close to the steady state, in which deviations from the long-term values should be orthogonal to country fixed effects after controlling for covariates. It is generally difficult to assert whether such conditions are fulfilled.

${ }^{13}$ The power of the Hansen test is generally low for a large instrument set. We minimize such a problem by choosing a parsimonious set of instruments.
} 
such additional effects, which need to be estimated over longer horizons because of the high persistence of the real interest rate. In addition, nominal rate fluctuations should be important for any real rate effect in levels, but they are not identified in our setting because we consider only country deviations from the eurozone average and eurozone members share the same nominal rate.

Table 4 provides the corresponding results for money market flows. The estimated autocorrelation for money market flows is between 0.32 and 0.37 , similar to that for equity fund flows. The point estimates for the flow effect of the real short rate changes in Columns 1-3 are, respectively, 7.7, 8.4, and 7.7 for LSDV, DGMM1, and DGMM2 specifications, suggesting that a decrease in the short-term real interest rate by 10 basis points predicts a quarterly money market outflow of about $0.8 \%$ of fund assets. This implies a permanent outflow effect of roughly $1.3 \%[\approx 0.84 \% /(1-0.36)]$ of fund assets or about $€ 7.3$ billion in money market flows.

Overall, the results indicate quantitatively strong equity fund inflows whenever the local monetary policy environment is loose relative to the eurozone average. The corresponding results for money market funds are also economically large, albeit with a lower level of statistical significance.

\subsection{The effect of local business cycles}

The evidence of a statistically and economically significant correlation between local real short rates and equity fund flows presented in Subsection 4.1 can have different causal interpretations. In line with a risk-taking channel of monetary policy, low real interest rates can push investors into riskier equity fund investments. Alternatively, changes in various macroeconomic variables can drive both inflation and local investor fund flows directly, thus creating a spurious correlation between the real short rate and investor fund allocation.

Previous empirical work on eurozone inflation rates has identified the local output gap as an important driver of inflation difference across eurozone member countries (Andersson, Masuch, 
and Schiffbauer, 2009). Therefore, we add changes in the output gap as a control variable in Table 3. Changes in the value added tax are also likely to influence the local inflation level. Thus, a twice-differenced measure of the local value added tax $(\Delta \Delta V A T)$ should capture the tax-induced inflation change and represents our second control variable. Local credit growth (gCredit) and local GDP growth $(g G D P)$ represent additional business cycle variables that could drive local inflation and simultaneously influence local fund allocation directly.

Table 3, Column 6, augments the base regression in Column 2 by these four business cycle variables. We find that none of these four additional control variables has any statistically significant explanatory power for equity fund flows. Moreover, the point estimate for the real short rate change $(\Delta S R)$ remains quantitatively unchanged in the augmented specification with a similar level of statistical significance. Inclusion of the same variables at lag 0 or at larger lags of 1-3 quarters does not alter this result either. The same holds for measurement of these variables at the annual frequency (calculated as the average of lags 0-3). In all these alternative specifications, the control variables are statistically insignificant, and the coefficient for the short rate remains stable and statistically significant at the $1 \%$ level. We conclude that these four local business cycle variables do not exert any direct influence on equity fund flows.

Other robustness checks augment the set of control variables further by adding changes of a country's comparative price level relative to the eurozone average, changes of country-level firm profitability proxied by the quarterly return on assets, and changes in the growth of quarterly government spending. Inclusion of these additional business cycle variables at lags 0-3 or as yearly averages again shows no evidence of a direct effect of these variables on equity flows and leaves the real short rate effect unchanged. $^{14}$

The findings also extend to the money market fund flows. Columns 6-7 of Table 4 report the augmented flow regression results for money market funds using, respectively, the DGMM

\footnotetext{
${ }^{14}$ Among these seven control variables, only the output gap and a country's comparative price level relative to the eurozone average feature statistically significant explanatory power for inflation differences of eurozone members during our sample period. The results are available upon request.
} 
and SGMM specifications. Inclusion of the four additional business cycle variables ( $\Delta$ Output Gap, $\Delta \Delta V A T, \Delta g C r e d i t$, and $\Delta g G D P)$ again shows no indication of a statistically significant direct influence of these variables on money market flows beyond the effect captured by the short rate changes.

\subsection{Equity flows by investment destination}

Our failure to find any local business cycle variable with a direct effect on fund flows (Subsection 4.2) does not rule out the possibility that unobservable local investor expectations about firm profitability could drive both local inflation and asset reallocation into equity funds. However, such asset reallocation should concern equity funds that invest mainly in the domestic market. This suggests a split of local equity fund flows by investment destination to control for unobservable productivity shocks that correlate with local inflation. We split the equity fund sample into 15, 467 funds investing more than half their assets in domestic equity and the remaining 58, 300 funds investing mainly in foreign equity. We then calculate a country's net aggregate equity fund inflow by its investment destination.

Columns 7 and 8 of Table 3 present the DGMM and SGMM estimates of the equity flow regression for funds with a foreign investment focus. The real short rate change, $\Delta S R$, shows a statistically significant equity flow effect, with the point estimate of -11.06 for DGMM and -12.28 for SGMM, which are slightly larger than the estimates for the full sample. Fig. 4 illustrates the negative relation between the predicted (instrumented) component of the real short rate change and the quarterly aggregate equity fund inflows with a domestic (foreign) investment focus in Panel A (B). ${ }^{15}$ The negative relation extends from mostly domestically invested flows to mostly foreign invested equity flows and is even stronger for the latter. The strong effect of the local real rate change on investment flows into foreign equity is difficult to reconcile with a direct pull effect from the local business cycle because improved cash flow

\footnotetext{
${ }^{15}$ The information on a fund's investment focus is based on data obtained from Lipper as of December 2010.
} 
expectations in a local boom should primarily trigger flows into funds with a local investment focus but not funds with a foreign investment focus.

Market clearing implies that net purchases of stocks by local fund investors need to be balanced by corresponding net sales by other local investors or foreign stock investors. Because foreign investors have a different consumption basket, they might not be subject to changes in the local inflation rate and real short rate and, therefore, (ceteris paribus) are likely to accommodate asset demand changes from local investors. In this case, local equity fund inflows can crowd out foreign equity investment.

Based on the data on the foreign equity portfolio investment position available for the US, we can verify this contrarian investment behavior for US investors. ${ }^{16}$ Curcuru, Thomas, Warnock, and Wongswan (2011) show that US investors' foreign holdings resemble the market portfolio of the destination country, allowing us to estimate the quarterly US investor net equity flows into each eurozone member country as the change in the quarterly holding value adjusted for the return of the holdings over the period. We measure these net US equity investment flows relative to their beginning-of-the-quarter value and regress them on the respective aggregate flows of local equity funds (that invest mainly in domestic markets). The negative regression coefficient of $-0.222(t$-statistic $=-3.45)$ confirms the contrarian behavior of US portfolio investors.

We further decompose local equity fund flows into a component predictable by the real short rate changes and a residual component. Regressing US net portfolio flows on both local fund flow components shows a negative coefficient for both. The local flow predicted by real short rate changes is highly statistically significant in a pooled regression with the country weight given by LocInstShare (i.e., the proportion of the local stock market held by local institutional

\footnotetext{
${ }^{16}$ Because reliable non-US foreign equity flows and stocks data are not available for eurozone member countries during our sample period, we provide evidence based solely on the aggregate foreign holdings of US investors. We thank Carol C. Bertaut for providing data on the aggregate foreign equity holdings of US investors, which are estimated based on the methodology described in Bertaut and Tryon (2007).
} 
investors), suggesting that a larger domestic investment bias by local equity funds corresponds to a more pronounced contrarian investment behavior by foreign portfolio investors from the US. $^{17}$

\subsection{Inflation expectations}

So far, we have used the realized real rate changes as the explanatory variable of interest. Using lagged realized changes as instruments (in the DGMM and SGMM regressions) means that we effectively use the predictable component of the real rate change as a regressor. Such an approach is appropriate if investors generally learn about the realized inflation with a quarter's delay. In this subsection, we go one step further and estimate the expected real rate change more precisely based on the data from European Commission's Consumer Survey. We calibrate for each country the average household inflation prediction from the national consumer surveys to the quarterly realized inflation process to obtain the expected local inflation rate and then the expected real short rate change $[\Delta S R$ (expected) $] .{ }^{18}$

Tables 5 and 6 replicate Tables 3 and 4 but replace the real short rate with the expected real short rate. Incorporating quarterly household expectations of inflation into the regression generally increases the magnitude for the coefficient of the real rate. For example, the coefficient drops by $29 \%$ from -9.1 (reported in Table 3, Column 6) to -11.7 in Table 5, Column 6. This suggests that the expected inflation component captured by the consumer survey data helps to explain the risk shifting into equity. A qualitatively similar result is obtained for the money market flow regressions. The regression coefficient for $\Delta S R$ (expected), reported in Table 6 , increases relative to $\Delta S R$ (reported in Table 4) in economic and statistical significance for every specification reported in Columns 1-7. The overall evidence suggests that the local error component in the household inflation forecast adds explanatory power to both local equity and

\footnotetext{
${ }^{17}$ See Table A3 of the Web Appendix for details.

${ }^{18}$ See Arnold and Lemmen (2008) for a more detailed analysis of eurozone inflation expectations. We construct the (survey data augmented) expected real short rate using the approach described in Table A1.
} 
money market flows.

\subsection{Robustness}

We undertake a variety of robustness checks. First, we verify the stability of our results for the precrisis period covering 2003/q1-2007/q2. The results reported in Table 7, Panel A, show very similar coefficient estimates for the full sample for both equity fund flows (Columns 1-2) and money market fund flows (Columns 3-4), suggesting that our finding is not driven by the crisis period.

Second, we construct local Taylor rule residuals as an alternative measure of the local policy conditions, following the approach used by Maddaloni and Peydró (2011). Table 7, Panel B, shows that the results for changes in Taylor rule residuals $(\Delta T R)$ are again qualitatively very similar to those for $\Delta S R$. The numerically larger point estimates for the $\Delta T R$ coefficient (e.g., -13.9 and 12.28 for $\Delta T R$ versus -9.52 and 8.38 for $\Delta S R$ based on the DGMM estimates) reflect the fact that the standard deviation of the Taylor rule residual changes is on average $24 \%$ smaller than that of the real short rate changes.

Third, to verify that our results are robust to the exclusion of the three crisis countries (Italy, Portugal, and Spain), we re-do the analysis without these three countries. The results reported in Table 7, Panel $\mathrm{C}$, indicate an equally strong asset allocation effect of monetary policy for this subsample. For example, the DGMM estimate of $\Delta S R$ is -7.64 (9.18) for equity (money market) funds, compared with the corresponding estimate of -9.52 (8.38) in the full sample.

\section{Stock price effects of real rate changes}

\subsection{Identification issues}

A major policy concern of low short-term interest rates is asset price inflation, which could result from investor risk shifting from low-yielding fixed income to high-risk equity investment, 
as shown in the Section $4 .{ }^{19}$ Unlike the riskless rate effect, which should affect assets (of similar duration) alike, the risk-shifting hypothesis of monetary policy predicts that stocks subject to (monetary policy-related) fund inflows should experience a relatively stronger price appreciation than benchmark stocks of low investability. This implies two identification challenges. First, we need to measure fund returns relative to a local benchmark that is not subject to any asset reallocation effect related to monetary policy. Second, we need to isolate equity fund flows induced by monetary policy conditions from all other (non monetary policy-related) fund flows.

Fund returns by definition proxy for returns of those stocks in which funds already invest heavily and into which they are likely to channel further investment. Any flow-related price pressure should be captured by the average fund return. By contrast, local stocks of low investability should not be subject to the investor asset reallocation effect (or at least in an attenuated manner) but nevertheless capture changes in the riskless rate and other shocks to the local economy. ${ }^{20}$ For each country, we construct a Low Fund Holding Index based on the returns of the $20 \%$ stocks with the lowest fund holdings over the previous three-year period. Because fund flows should primarily impact the returns of the flow-sensitive stocks that constitute the investment universe of the local funds, we can construct a fund size-weighted aggregate local fund return index, FundReturn $n_{c, t}$, and identify price pressure as its excess return over the benchmark index $L F H I_{c, t}$ of non-investable stocks:

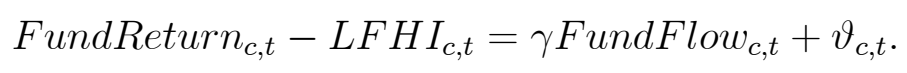

\footnotetext{
${ }^{19}$ For example, Jotikasthira, Lundblad, and Ramadorai (2012) show that aggregate fund flows relate to sizable stock price effects.

${ }^{20}$ Importantly, this measure allows us to filter out any unobservable countrywide shocks on firm profitability, which can correlate with monetary shocks. The stock price effect of such macro shocks will not affect our measure unless the cash flow impact of such shocks affects the benchmark and non-benchmark stocks differently. We verify that both the benchmark and non-benchmark stocks spread across all industries in our sample, so real shocks are likely to produce similar aggregate stock price impact on both stock samples in each country. Furthermore, the concern that benchmark stocks and non-benchmark stocks can feature different degrees of liquidity (and thus different expected returns) should not matter for our inference as long as such liquidity differences relate to stock characteristics and do not depend on local monetary policy conditions.
} 
The parameter $\gamma$ captures the average quarterly return elasticity of fund flows, and $\vartheta_{c, t}$ represents the residual return effects unrelated to fund flows in country $c$.

The second identifying step involves isolating the predictable fund flows induced by the crosssectional variation in eurozone monetary policy conditions from all other fund flows represented by the residual $\kappa_{c, t}$. In the flow decomposition

$$
\text { FundFlow }_{c, t}=\text { FundFlow }_{c, t}+\kappa_{c, t}
$$

we can use the coefficients estimated from the flow regressions to obtain the predicted fund flows that are triggered by changes in short-term real interest rates as follows:

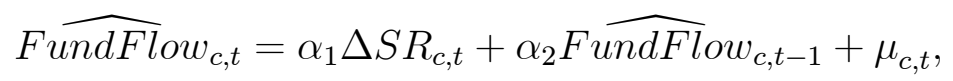

where the coefficients $\alpha_{1}$ and $\alpha_{2}$ correspond to the estimates obtained in Eq. (1). To derive the predicted fund flows strictly from changes in short-term real interest rates, we drop the market returns from the equation. Similarly, we can further relate $F \widehat{\text { undFlow }} w_{c, t-1}$ to lagged changes of short-term real interest rates. Substitution of Eqs. (3) and (4) into Eq. (2) yields the specification

$$
\text { FundReturn }_{c, t}-\operatorname{LFHI}_{c, t}=\beta_{0}+\beta_{1} \Delta S R_{c, t}+\beta_{2} \Delta S R_{c, t-1}+\beta_{3} \Delta S R_{c, t-2}+\nu_{j}+\varepsilon_{c, t},
$$

with linear constraints $\beta_{1}=\gamma \alpha_{1}, \beta_{2}=\gamma \alpha_{1} \alpha_{2}$, and $\beta_{3}=\gamma \alpha_{1} \alpha_{2} \alpha_{2}$, and lagged terms $\Delta S R_{c, t-k}$ with $k>2$ ignored. Eq. (5) can be estimated simultaneously with Eq. (4) under the constraints $\beta_{2}=\alpha_{2} \beta_{1}$ and $\beta_{3}=\alpha_{2} \beta_{2}$. The sum of the constrained coefficients $\beta_{1}, \beta_{2}$, and $\beta_{3}$ directly reveals the cumulative return effect of changes in short-term real interest rates and thus identifies the role of the risk-shifting channel of monetary policy on the equity prices of those stocks with strong fund flows. 


\subsection{Evidence}

Table 8 provides the estimation results for Eqs. (4) and (5). In Columns 1-4, we report regressions in which each country has the same regression weight, $1 / 8$. Because the share of the local capital market held by local institutional investors [LocInstShare $(c)]$ varies greatly for our sample, from $1.1 \%$ in Austria to $10.7 \%$ in Germany, we expect the fund flows from local investors identified in Eq.(5) to have a significantly larger price impact in Germany than in Austria. Therefore, in Columns 5-8, we use LocInstShare(c) as the country weight to better capture price pressure impact, and we expect the estimated coefficients $\beta_{1}, \beta_{2}$, and $\beta_{3}$ in Eq. (5) to increase in this case. We estimate the system of equations both for the real short rate changes $\Delta S R$ and for the expected short rate changes $\Delta S R$ (expected). Specifications $1,3,5$, and 7 feature no fixed effects for the second equation, and country fixed effects are added in Specifications 2, 4, 6, and 8 .

Estimation of the first equation is undertaken in first differences similar to the DGMM estimates reported in Tables 3 and 5, Column 2. Overall, the corresponding coefficient for changes in real short rates, $\Delta S R$ or $\Delta S R$ (expected), ranges from -10 to -14 , slightly larger than the previous single-equation estimates of -9.5 (reported in DGMM1 of Table 3) and -12.2 (reported in DGMM1 of Table 5).

In the second equation, we impose the restriction that flows triggered by innovations to the real short rates $(\Delta S R)$ have a constant price impact $\gamma$ over time on contemporaneous fund excess returns. The total excess return effect consists of the sum $\widehat{\beta}_{1}+\widehat{\beta}_{2}+\widehat{\beta}_{3}$. Under equal country weights in Columns $1-2$, the total return effect of $\Delta S R$ is approximately $\widehat{\beta}_{1}+\widehat{\beta}_{2}+\widehat{\beta}_{3} \approx$ -20 , implying that a decrease of 10 basis points in the short-term real interest rate increases the relative valuation of flow-sensitive stocks by roughly $2 \%$. However, the standard errors for the coefficients are large, rendering the $t$-statistics only marginally significant.

By contrast, the results in Columns 5-6, with the country weights based on local institutional 
investor share, imply economically and statistically significant price pressure effects, with $\widehat{\beta}_{1}+$ $\widehat{\beta}_{2}+\widehat{\beta}_{3} \approx-40$. The point estimates of $\widehat{\beta}_{1}+\widehat{\beta}_{2}+\widehat{\beta}_{3}$ are even more negative if the real short rate is replaced by the expected real short rate $\Delta S R$ (expected) in Columns $7-8$. The estimate in Column 8 suggests that a decrease of 10 basis points in the real rate boosts relative fund returns in investable stocks by $5 \%$. The results suggest that the equity fund inflows triggered by an accommodating monetary policy have a much larger effect on the stock prices of countries in which local institutional investors are important.

As a robustness check, we experiment with variations of the $20 \%$ threshold for stock inclusion in the Low Fund Holding Index, using either a $15 \%$ or $25 \%$ cutoff. Overall, the quantitative return results of Table 8 become slightly stronger for the $15 \%$ threshold and slightly weaker for the more inclusive $25 \%$ cutoff, but the results remain qualitatively robust across such modifications.

The implied asset price effect of monetary policy appears to be large if the estimates of Table 8 are applied to the absolute real rate changes experienced over the recent period. The EONIA rate dropped from an average of 4.3\% in August 2008 to $0.3 \%$ in August 2009. The implied incremental equity price inflation during this period is $80 \%$ (based on the estimates in Table 8, Column 2) for an average eurozone country and 160\% (based on the estimates in Table 8, Column 6) for countries with a high degree of investor home bias. Both point estimates suggest a substantial equity market overvaluation in the post-crisis period and a potential large market correction once the current extremely low nominal rates revert in the future. However, these point estimates need to be interpreted with caution because they are extrapolated under the assumption of linearity of the flow-equity return relation estimated based on cross-sectional real short rate variations in the range of -20 to +20 basis points.

A few limitations of our inference on equity price inflation should be highlighted. First, we infer the price pressure from the aggregate portfolio of fund holdings, which typically differs from the value-weighted local market index with slightly larger investment weights in large- 
cap stocks. If stocks with low institutional ownership are less price-sensitive to interest rate changes, we could overestimate the return effect on the local equity market. Yet, the aggregate local fund portfolio and the value-weighted local market portfolio tend to be relatively similar (with a return correlation of 0.914 ), limiting the scope for a large price discrepancy between the two portfolios. Second, we identify the flow sensitivity to real rate changes only for local fund investors and ignore portfolio flows from all other local investors. However, the return equation in Table 8 nevertheless captures the price effect of non-fund flows as well if they occur in parallel to the observed fund flows. From this perspective, the estimated equity return effect can be representative of the overall risk shifting of all local investors. Third, we concede certain shortcomings of the benchmark group of non-investable stocks. These stocks can still be subject to a (small) amount of price pressure, implying that the incremental return effect of the fund portfolio return underestimates the inflationary effect of real short rate changes. Importantly, monetary policy measure can directly influence the discount factor for both investable and noninvestable stocks and, therefore, could also contribute to an underestimation of the monetary policy effect on equity prices.

\section{Conclusion}

The recent financial crisis has put research on financial stability and its determinants back on center stage. An important and unresolved issue remains the role of monetary policy as a contributing factor to instability, particularly if it is very accommodating. This paper contributes to this research agenda by looking directly at the investor asset allocation process in eight eurozone countries, which feature a tight link between the investment decisions of retail investors and fund flows to equity and money market funds in the respective countries.

First, we find that loose local monetary policy conditions, measured by a decrease in the real short-term interest rate relative to the ECB monetary policy at the currency union level, are associated with a strong investor flow out of money market funds and into equity funds 
even after controlling for contemporaneous local business cycle shocks. The evidence is equally strong for flows into equity funds with a primarily foreign investment focus, suggesting that changing firm cash flow expectations related to the local business cycle cannot explain the risk shifting into equity investment.

Second, we explore whether the asset reallocation process explained by local monetary policy conditions contributes to equity price inflation. We find that investor asset reallocation toward equity funds triggered by loose local monetary policy conditions generates the greatest stock price inflation in countries in which local institutional investors hold a large share of the local stock market. This might not be surprising because asset prices ought to be more exposed to risk shifting in reaction to the local real short rate change in markets where local investors are relatively more important. By contrast, financially open economies are more likely to spread asset price inflation globally.

Overall, we interpret our evidence as support for an economically significant link between monetary policy and investors' asset allocation decisions. Loose monetary policy appears to contribute to investor risk taking through increased equity investment with local equity price inflation as a consequence. It is often difficult for central banks to identify this monetary policy component of asset price inflation, partly due to high overall stock market volatility. Knowledge about investors' asset allocation decisions can serve as a useful complementary source of information about investor risk choices. A prudential policy framework should therefore monitor asset prices in conjunction with micro-level data on investor risk allocations.

Our study also has implications for issues related to the financial stability of a currency union. While a currency union, such as the eurozone, clearly sacrifices local monetary autonomy for the sake of capital mobility and fixed internal exchange rates, it is more controversial if the ensuing variation of local monetary policy conditions inside the currency union also gives rise to financial instability. A recent study by Bordo and James (2014) argues that currency pegs (such as the gold standard or more recently the common currency in the eurozone) augment variations 
in local monetary policy conditions and thus further financial instability. Our evidence on investor risk seeking as a function of local monetary policy conditions is consistent with such a view. Importantly, we also find that the relative asset price inflation in national equity markets strongly depends on the extent of international diversification in investor equity holdings. Our result suggests that a high degree of financial integration could be a prerequisite for a stable currency union. 
Table A.1. Variable definitions

\begin{tabular}{|c|c|c|}
\hline Variable & Description & Source \\
\hline$S R$ & $\begin{array}{l}\text { Quarterly short-term real interest rate, calculated as the differ- } \\
\text { ence between EOINA and the quarterly inflation rate. }\end{array}$ & Datastream \\
\hline$S R$ & Difference between the quarterly EONIA and the quarterly ex- & Datastream \\
\hline \multirow[t]{20}{*}{ (expected) } & pected inflation rate derived from the European Commission's & and Eurostat \\
\hline & Consumer Survey data. Each month, consumers in the euro- & \\
\hline & zone countries are asked the following question on future prices & \\
\hline & (Question 6): "By comparison with the past 12 months, how do & \\
\hline & you expect consumer prices will develop in the next 12 months? & \\
\hline & They will (1) increase more rapidly, (2) increase at the same & \\
\hline & rate, (3) increase at a slower rate, (4) stay about the same, & \\
\hline & (5) fall, or (6) don't know." Let $S_{i}$ denotes the proportion of & \\
\hline & consumers choosing option $i$. The Balance $(B A L)$ statistic is & \\
\hline & calculated as $B A L=S_{1}+0.5 \times S_{2}-S_{5}-0.5 \times S_{4}$. Using & \\
\hline & the quarterly data from $2003 / q 1-2010 / q 4$ for the eight sample & \\
\hline & countries, we run the following pooled regression: $I N F_{c, t+1}=$ & \\
\hline & $\beta_{0}+\beta_{1} \times I N F_{c, t}+\beta_{2} \times B A L_{c, t}+\beta_{3} \times I N F_{c, t} \times B A L_{c, t}+\epsilon_{c, t}$ & \\
\hline & where $c$ and $t$ are country and quarter subscripts. We obtain & \\
\hline & the following estimates: $\beta_{0}=0.001[t=3.12], \beta_{1}=0.783$ & \\
\hline & {$[t=18.95], \beta_{2}=0.003[t=2.54]$, and $\beta_{3}=0.029[t=$} & \\
\hline & 0.15]. The total number of observations is 256 , and the ad- & \\
\hline & justed $R$-squared is 0.745 . The expected inflation for quarter & \\
\hline & $t+1$ is then estimated by the fitted value of the regression: & \\
\hline & $0.001+0.783 \times I N F_{c, t}+0.003 \times B A L_{c, t}+0.029 \times I N F_{c, t} \times B A L_{c, t}$ & \\
\hline
\end{tabular}




\begin{tabular}{|c|c|c|}
\hline Variable & Description & Source \\
\hline EONIA & Quarterly average of the overnight interest rate in the euro area. & Datastream \\
\hline$I N F$ & Quarterly inflation rate. & Datastream \\
\hline$M K T$ & Quarterly return on the MSCI country market index. & Datastream \\
\hline FundReturn & $\begin{array}{l}\text { Aggregate quarterly value-weighted net fund return. For each } \\
\text { quarter we calculate the average return of all equity (or money } \\
\text { market) funds in a country, with individual fund returns } \\
\text { weighted by each fund's beginning-of-period fund } T N A \text {. }\end{array}$ & Lipper \\
\hline$T N A$ & Total net asset value of a fund in euros. & Lipper \\
\hline $\begin{array}{l}\text { Aggregate } \\
\text { FundFlow }\end{array}$ & $\begin{array}{l}\text { Aggregate equity (or money market) fund flow for a country es- } \\
\text { timated by the aggregate net euro flow of all equity (or money } \\
\text { market) funds in a country scaled by these funds' aggregate } \\
\text { beginning-of-period } T N A \text {. A fund's net euro flow is estimated } \\
\text { by the difference between the end-of-period } T N A \text { and the prod- } \\
\text { uct of the beginning-of-period } T N A \text { and } 1 \text { plus the current fund } \\
\text { return. }\end{array}$ & Lipper \\
\hline$\Delta$ Output Gap & $\begin{array}{l}\text { Quarterly change of the output gap. Output gap is measured } \\
\text { by the difference between actual gross domestic product (GDP) } \\
\text { and potential GDP scaled by potential GDP. We interpolate the } \\
\text { quarterly observations from the annual output gap data obtained } \\
\text { from the Organization for Economic Co-operation and Develop- } \\
\text { ment (OECD). The potential GDP is estimated using a produc- } \\
\text { tion function approach. }\end{array}$ & OECD \\
\hline$\Delta \Delta V A T$ & $\begin{array}{l}\text { Twice difference of the value added tax (VAT) rate. We inter- } \\
\text { polate the quarterly observations from the annual data obtained } \\
\text { from the OECD. }\end{array}$ & OECD \\
\hline
\end{tabular}




\begin{tabular}{|c|c|c|}
\hline Variable & Description & Source \\
\hline \multirow[t]{3}{*}{$\Delta g C r e d i t$} & Quarterly change of growth in total credit to private nonfinancial & Bank \\
\hline & sectors. & International \\
\hline & & Settlement \\
\hline$\Delta g G D P$ & Change in the quarterly growth of real GDP. & Datastream \\
\hline \multirow[t]{9}{*}{$T R$} & Residual of a pooled regression of EONIA on the quarterly real & Datastream \\
\hline & $G D P$ growth and inflation rate, with the constraint that the & \\
\hline & regression coefficients are the same across the eurozone countries: & \\
\hline & $E O N I A_{t}=\delta_{0}+\delta_{1} \times g G D P_{c, t}+\delta_{2} \times I N F_{c, t}+T R_{c, t}$, where $c$ & \\
\hline & and $t$ denote country and quarter subscripts. Using the data & \\
\hline & from 2003/1-2010/4 for the eight sample countries, we obtain the & \\
\hline & following estimates: $\delta_{0}=0.003[t=8.48], \delta_{1}=0.009[t=0.55]$ & \\
\hline & and $\delta_{2}=0.658[t=11.78]$. The total number of observations is & \\
\hline & 256 , and the adjusted $R$-squared is 0.349 . & \\
\hline \multirow[t]{4}{*}{$L F H I$} & Quarterly return on the value-weighted index of the $20 \%$ of & Thomson \\
\hline & stocks with the lowest average fund holdings over the previous & Financial and \\
\hline & three years. Fund holdings are aggregated across all funds and & Datastream \\
\hline & scaled by a stock's shares outstanding. & \\
\hline
\end{tabular}




\begin{tabular}{lll}
\hline Variable & \multicolumn{1}{c}{ Description } & Source \\
\hline LocInstShare & Average free-float adjusted local institutional ownership for the & Bartram, \\
& quintile of firms with the largest market capitalization value. Griffin, and \\
& The ownership calculation is based on the pool of domestic insti- $\mathrm{Ng}(2014)$ \\
& tutions that report their asset holdings to the FactSet database. \\
& The average is first taken by year from $2000 / q 1$ to $2009 / q 1$ and \\
& then across time. We obtain the data from Table A3 of Bartram, \\
Griffin, and Ng (2014).
\end{tabular}




\section{References}

[1] Adrian, T., Shin, H. S., 2010. Financial intermediaries and monetary economics. In: Friedman, B. M., Woodford, M. (Eds), Handbook of Monetary Economics. Elsevier, New York, NY, pp. 601-650.

[2] Altunbas, Y., Gambacorta, L., Marquéz-Ibañez, D., 2014. Does monetary policy affect bank risk taking? International Journal of Central Banking 10 (1), 95-135.

[3] Álvarez, L., Dhyne, E., Hoeberichts, M., Kwapil, C., Bihan, H., Lünnemann, P., Martins, F., Sabbatini, R., Stahl, H., Vermeulen, P., Vilmunen, J., 2006. Sticky prices in the euro area: a summary of new micro-evidence. Journal of the European Economic Association $4(2-3), 575-584$.

[4] Andersson, M., Masuch, K., Schiffbauer, M., 2009. Determinants of inflation and price level differentials across the euro area countries. Working paper series no. 1129, European Central Bank, Frankfurt, Germany.

[5] Arciero, L., Heijmans, R., Heuver, R., Massarenti, M., Picillo, C., Vacirca, F., 2014. How to measure the unsecured money market? The Eurosystem's implementation and validation using TARGET2 Data. Unpublished working paper. European Central Bank, Frankfurt, Germany.

[6] Arellano, M., Bond, S., 1991. Some tests of specification for panel data: Monte Carlo evidence and an application to employment equations. Review of Economic Studies 58 (2), 277-297.

[7] Arellano, M., Bover, O., 1995. Another look at the instrumental variables estimation of error components models. Journal of Econometrics 68 (1), 29-51. 
[8] Arnold, I., Lemmen, J., 2008. Inflation expectations and inflation uncertainty in the eurozone: evidence from survey data. Review of World Economics 144 (2), 325-346.

[9] Bartram, S. M., Griffin, J., Ng, D. T., 2014. How important are foreign ownership linkages for international stock returns? Unpublished working paper. Cornell University, Ithaca, NY.

[10] Bekaert, G., Hoerova, M., Lo Duca, M., 2013. Risk, uncertainty, and monetary policy. Journal of Monetary Economics 60 (7), 771-788.

[11] Bernanke, B. S., 2002. Asset price bubbles and monetary policy. Speech. New York Chapter of the National Association of Business Economists, New York Chapter, New York, NY.

[12] Bernanke, B. S., Gertler, M., 1999. Monetary policy and asset price volatility. Economic Review (Fourth Quarter), 17-51.

[13] Bernanke, B. S., Gertler, M. 2001. Should central banks respond to movements in asset prices? American Economic Review 91 (2), 253-257.

[14] Bernanke, B., Kuttner, K. N., 2005. What explains the stock market's reaction to Federal Reserve policy? Journal of Finance 60 (3), 1221-1257.

[15] Bertaut, C. C., Tryon, R. W., 2007. Monthly estimates of US cross-border securities positions. International finance discussion paper no. 910, Federal Reserve Board, Washington, DC.

[16] Bjørnland, H. C., Leitemo, K., 2009. Identifying the interdependence between US monetary policy and the stock market. Journal of Monetary Economics 56, 275-282.

[17] Blundell, R., Bond, S., 1998. Initial conditions and moment restrictions in dynamic panel data models. Journal of Econometrics 87, 115-143. 
[18] Boissel, C., Derrien, F., Örs, E., Thesmar, D., 2014. Sovereign crises and bank financing: evidence from the European repo market. Unpublished working paper. HEC Paris, Jouyen-Josas, France.

[19] Bond, S., Hoeffler, A. Temple, J., 2001. GMM estimation of empirical growth models. Economics discussion paper 01/525. University of Oxford, Oxford, UK.

[20] Bordo, M. D., James, H., 2014. The European crisis in the context of the history of previous financial crises. Journal of Macroeconomics 39, 275-284.

[21] Borio, C., Lowe, P., 2002. Asset prices, financial and monetary stability: exploring the nexus. Working papers no. 114, Bank for International Settlements, Basel, Switzerland.

[22] Borio, C., Zhu, H., 2012. Capital regulation, risk taking, and monetary policy: a missing link in the transmission mechanism? Journal of Financial Stability 8 (4), 236-251.

[23] Cecchetti, S. G., Genberg, H., Lipsky, J., Wadhwani, S., 2000. Asset prices and Central Bank policy. Geneva Report on the World Economy, no. 2, Center for Economic Policy Research, London, UK.

[24] Chen, H., Noronha, G., Singal, V., 2004. The price response to S\&P 500 index additions and deletions: evidence of asymmetry and a new explanation. Journal of Finance 59 (4), 1901-1929.

[25] Curcuru, S., Thomas, C., Warnock, F., Wongswan, J., 2011. US international equity investment and past and prospective returns. American Economic Review 101 (7), 3440-3455.

[26] De Nicolò, G., Dell'Ariccia, G., Laeven, L., Valencia, F., 2010. Monetary policy and bank risk taking. Staff position note. International Monetary Fund, Washington, DC.

[27] European Central Bank, 2012. Euro money market study. December. European Central Bank, Frankfurt, Germany. 
[28] Gambacorta, L., 2009. Monetary policy and the risk-taking channel. BIS Quarterly Review (December), 43-53

[29] Goetzmann, W., Massa, M., 2003. Index funds and stock market growth. Journal of Business $76(1), 1-29$.

[30] Hau, H., Lai, S. 2013. The role of equity funds in the financial crisis propagation. Research paper no. 11-35. Swiss Finance Institute, Geneva, Switzerland.

[31] Hellwig, M., 2011. Quo vadis Euroland? European monetary union between crisis and reform. Unpublished working paper. Max Planck Institute for Research on Collective Goods, Bonn, Germany.

[32] Holtz-Eakin, D., Newey, W., Rosen H. S., 1988. Estimating vector autoregressions with panel data. Econometrica 56, 1371-1395.

[33] Ioannidou, V. P., Ongena, S., Peydró, J.-L., 2009. Monetary policy, risk-taking and pricing: evidence from a quasi-natural experiment. Discussion paper no. 2009-04S. European Banking Center, Tilburg, the Netherlands.

[34] Issing, O., 2009. In search of monetary stability: the evolution of monetary policy. Working paper no. 273. Bank for International Settlements, Basel, Switzerland.

[35] Jiménez, G., Ongena, S., Peydró, J.-L., Saurina, J., 2014. Hazardous times for monetary policy: what do 23 million bank loans say about the effects of monetary policy on credit risk-taking? Econometrica 82 (2), 463-505.

[36] Jotikasthira, C., Lundblad, C., Ramadorai, T. 2012. Asset fire sales and purchases and the international transmission of funding shocks. Journal of Finance 67 (6), 2015-2050. 
[37] Kohn, D. L., 2006. Monetary policy and asset prices. Speech. European Central Bank colloquium, "Monetary Policy: A Journey from Theory to Practice," held in honor of Otmar Issing, Frankfurt, Germany.

[38] Kohn, D. L., 2008. Monetary policy and asset prices revisited. Speech. Cato Institute's 26th Annual Monetary Policy Conference, Washington, DC.

[39] Maddaloni, A., Peydró J.-L., 2011. Bank risk-taking, securitization, supervision, and low interest rates: evidence from the euro-area and the US lending standards. Review of Financial Studies 24 (6), 2121-2165.

[40] Mancini, L., Ranaldo, A., Wrampelmeyer, J., 2014. The euro interbank repo market. Unpublished working paper. University of St. Gallen, St. Gallen, Switzerland.

[41] Mitchell, O., Mottola, G., Utkus, S., Yamaguchi, T., 2006. The inattentive participant: portfolio trading behavior in 401(k) plans. Unpublished working paper. University of Michigan, Ann Abor, MI.

[42] Moretti, L., 2013. The determinants of inflation differentials in the euro area. Unpublished working paper. Goethe University of Frankfurt, Frankfurt, Germany.

[43] Rajan, R., 2006. Has finance made the world riskier? European Financial Management 12 (4), 499-533.

[44] Rigobon, R., Sack, B., 2004. The impact of monetary policy on asset prices. Journal of Monetary Economics 51 (8), 1553-1575.

[45] Roodman, D. 2009. How to do xtabond2: an introduction to difference and system GMM in Stata. Stata Journal 9 (1), 86-136.

[46] Sercu, P., Vanpee, R., 2007. Home bias in international equity portfolios: a review. Unpublished working paper. KU Leuven, Leuven, Belgium. 
[47] Stock, J. H., Yogo, M., 2005. Testing for weak instruments in linear IV regression. In: Andrews, D. W. K., Stock, J. H. (Eds.), Identification and Inference for Econometric Models: Essays in Honor of Thomas J. Rothenberg. Cambridge University Press, New York, NY, 80-108.

[48] Taylor, J. B., 2008. Economic policy and financial crisis: an empirical analysis of what went wrong. Critical Review 21 (2-3), 341-364.

[49] Thorbecke, W., 1997. On stock market returns and monetary policy. Journal of Finance $52(2), 635-654$.

[50] Wicksell, K., 1898. Interest and Prices: A Study of the Causes Regulating the Value of Money. Tranlated by R. Kahn. Augustus M. Kelley, New York, NY, 1962. 
Table 1

Macroeconomic variables

Reported are the summary statistics of the quarterly overnight interest rates in the eurozone $(E O N I A)$, inflation rate $(I N F)$, change in output gap ( $\triangle$ Output Gap), first difference of the change in the value-added tax $(\Delta \Delta V A T)$, change in the growth of total credit to private nonfinancial sectors $(\Delta g$ Credit), and change in the quarterly real gross domestic product growth $(\Delta g G D P)$ for the sample countries. The summary statistics for the time series average proportion of the local stock market held by local institutional investors (LocInstShare) is also reported. The sample consists of Austria, Finland, France, Germany, Italy, the Netherlands, Portugal, and Spain over the period 2003/q1-2010/q4. We also report the actual short-term real interest rate $(S R)$ and expected short-term real interest rate $[S R$ (expected)] by country as well as their cross-country averages. The cross-country averages of changes in the actual short-term real interest rate $(\Delta S R)$ and expected short-term real interest rate $[\Delta S R$ (expected)] are also reported. All statistics are expressed in percent. See Table A.1 for variable definitions.

\begin{tabular}{|c|c|c|c|c|c|c|}
\hline Variable & $\begin{array}{l}\text { Number of } \\
\text { observations }\end{array}$ & Mean & Median & $\begin{array}{l}\text { Standard } \\
\text { deviation }\end{array}$ & Minimum & Maximum \\
\hline \multicolumn{7}{|c|}{ Macroeconomic variables $\times 100$} \\
\hline$E O N I A$ & 32 & 0.562 & 0.516 & 0.300 & 0.086 & 1.047 \\
\hline$I N F$ & 256 & 0.460 & 0.453 & 0.272 & -0.367 & 1.204 \\
\hline$\Delta$ Output Gap & 256 & -0.096 & 0.056 & 0.604 & -2.428 & 0.876 \\
\hline$\Delta \Delta V A T$ & 256 & 0.000 & 0.000 & 0.376 & -3.000 & 3.000 \\
\hline$\Delta g$ Credit & 256 & -0.018 & -0.110 & 1.688 & -8.341 & 7.530 \\
\hline$\triangle g G D P$ & 256 & 0.013 & -0.027 & 0.882 & -3.034 & 5.166 \\
\hline LocInstShare & 8 & 5.387 & 4.100 & 3.969 & 1.100 & 10.700 \\
\hline \multicolumn{7}{|c|}{ Short-term real interest rate $(S R) \times 100$} \\
\hline Austria & 32 & 0.101 & 0.118 & 0.246 & -0.399 & 0.506 \\
\hline Finland & 32 & 0.220 & 0.308 & 0.239 & -0.500 & 0.548 \\
\hline France & 32 & 0.140 & 0.126 & 0.250 & -0.312 & 0.678 \\
\hline Germany & 32 & 0.182 & 0.193 & 0.192 & -0.221 & 0.501 \\
\hline Italy & 32 & 0.053 & 0.031 & 0.224 & -0.293 & 0.594 \\
\hline Netherlands & 32 & 0.165 & 0.145 & 0.259 & -0.274 & 0.672 \\
\hline Portugal & 32 & 0.049 & -0.014 & 0.268 & -0.440 & 0.468 \\
\hline Spain & 32 & -0.096 & -0.155 & 0.260 & -0.480 & 0.408 \\
\hline All $S R$ & 256 & 0.102 & 0.101 & 0.258 & -0.500 & 0.678 \\
\hline All $\Delta S R$ & 256 & -0.016 & -0.008 & 0.117 & -0.411 & 0.333 \\
\hline \multicolumn{7}{|c|}{ Expected short-term real interest rate $[S R($ expected $)] \times 100$} \\
\hline Austria & 32 & 0.075 & 0.124 & 0.244 & -0.432 & 0.450 \\
\hline Finland & 32 & 0.180 & 0.258 & 0.217 & -0.531 & 0.446 \\
\hline France & 32 & 0.134 & 0.103 & 0.247 & -0.332 & 0.615 \\
\hline Germany & 32 & 0.158 & 0.173 & 0.186 & -0.237 & 0.454 \\
\hline Italy & 32 & 0.126 & 0.108 & 0.214 & -0.239 & 0.566 \\
\hline Netherlands & 32 & 0.151 & 0.171 & 0.238 & -0.330 & 0.544 \\
\hline Portugal & 32 & 0.021 & -0.052 & 0.256 & -0.531 & 0.431 \\
\hline Spain & 32 & -0.046 & -0.087 & 0.229 & -0.381 & 0.395 \\
\hline All $S R$ (expected $)$ & 256 & 0.100 & 0.113 & 0.238 & -0.531 & 0.615 \\
\hline All $\Delta S R$ (expected) & 256 & -0.018 & -0.005 & 0.101 & -0.326 & 0.268 \\
\hline
\end{tabular}


Table 2

Aggregate Fund Flows

Reported are the summary statistics for the net equity and money market fund flows at the aggregate country level for eight eurozone countries (Austria, Finland, France, Germany, Italy, the Netherlands, Portugal, and Spain) during the sample period 2003/q1-2010/q4. The aggregate fund flow is the aggregate net euro flow for all funds in a country scaled by their aggregate beginning-of-period total net asset value $(T N A)$. A fund's net euro flow is estimated by the difference between the end-of-period $T N A$ and the product of the beginning-of-period $T N A$ and 1 plus the current fund return. Also reported are the MSCI country market index return $(M K T)$ and the value-weighted index return for the $20 \%$ of stocks with the lowest fund holdings measured over the previous three-year period ( $L F H I$ ). The last row of the table reports the statistics for the aggregate fund size-weighted local fund returns (FundReturn).

\begin{tabular}{|c|c|c|c|c|c|c|}
\hline Variable & $\begin{array}{l}\text { Number of } \\
\text { observatons }\end{array}$ & Mean & Median & $\begin{array}{l}\text { Standard } \\
\text { deviation }\end{array}$ & Minimum & Maximum \\
\hline \multicolumn{7}{|c|}{ Aggregate equity fund flows } \\
\hline Austria & 32 & 0.007 & 0.007 & 0.039 & -0.083 & 0.101 \\
\hline Finland & 32 & 0.018 & 0.014 & 0.038 & -0.049 & 0.098 \\
\hline France & 32 & -0.008 & -0.008 & 0.013 & -0.035 & 0.021 \\
\hline Germany & 32 & -0.015 & -0.013 & 0.019 & -0.062 & 0.019 \\
\hline Italy & 32 & -0.031 & -0.018 & 0.034 & -0.128 & 0.009 \\
\hline Netherlands & 32 & -0.005 & -0.005 & 0.015 & -0.035 & 0.049 \\
\hline Portugal & 32 & 0.002 & 0.002 & 0.044 & -0.073 & 0.130 \\
\hline Spain & 32 & -0.012 & -0.003 & 0.065 & -0.205 & 0.087 \\
\hline All Fund Flow & 256 & -0.006 & -0.006 & 0.039 & -0.205 & 0.130 \\
\hline \multicolumn{7}{|c|}{ Aggregate money market fund flows } \\
\hline Austria & 32 & 0.002 & -0.018 & 0.068 & -0.110 & 0.182 \\
\hline Finland & 30 & 0.018 & -0.013 & 0.127 & -0.255 & 0.403 \\
\hline France & 32 & -0.005 & -0.013 & 0.040 & -0.067 & 0.113 \\
\hline Germany & 32 & -0.047 & -0.040 & 0.049 & -0.178 & 0.061 \\
\hline Italy & 32 & -0.024 & -0.025 & 0.041 & -0.119 & 0.053 \\
\hline Netherlands & 31 & -0.007 & -0.004 & 0.052 & -0.168 & 0.166 \\
\hline Portugal & 32 & -0.035 & -0.033 & 0.081 & -0.225 & 0.178 \\
\hline Spain & 32 & -0.031 & -0.021 & 0.046 & -0.159 & 0.053 \\
\hline All Fund Flow & 253 & -0.016 & -0.022 & 0.070 & -0.255 & 0.403 \\
\hline \multicolumn{7}{|c|}{ Equity Return Indices and Fund Returns } \\
\hline$M K T$ & 256 & 0.023 & 0.038 & 0.115 & -0.416 & 0.324 \\
\hline$L F H I$ & 256 & 0.028 & 0.032 & 0.109 & -0.340 & 0.365 \\
\hline Fund Return & 256 & 0.017 & 0.038 & 0.086 & -0.238 & 0.229 \\
\hline
\end{tabular}


Table 3

Equity fund flows and real rate changes

The quarterly country aggregate net inflows into equity funds domiciled and marketed in Austria, Finland, France, Germany, Italy, the Netherlands, Portugal, and Spain over the period 2003/q1-2010/q4 are regressed on changes in the local real short rate in each country $(\Delta S R)$. To eliminate the need for time fixed effects, all variables are expressed as deviations from their cross-sectional means. Column 1 provides the estimate using the least square dummy variable (LSDV) regression. Columns 2-3 and 4, respectively, provide the estimates using the difference generalized method of moments (DGMM) and system generalized method of moments (SGMM). Column 5 uses the same setup as Column 2 but includes four additional regressors: $\Delta$ Output Gap, $\Delta \Delta V A T, \Delta g C r e d i t$, and $\Delta g G D P$. Column 6 provides the DGMM estimate for the net aggregate equity flows based on funds that invest more than $50 \%$ of their fund assets in domestic stocks. Columns 7-8 focus on the net aggregate flows received by those local funds that invest more than $50 \%$ of their fund assets in foreign stocks. The regressors are changes in the short-term real interest rate $\Delta S R$; fund flows at lag 1 , given by FundFlow $(-1)$; the country stock market return in the previous quarter $M K T(-1)$; changes in output gap in the previous quarter, given by $\Delta$ Output Gap $(-1)$; first difference of the change in the value added tax (VAT) rate in the previous quarter, denoted by $\Delta \Delta V A T(-1)$; change in the growth of total credit to private nonfinancial sectors in the previous quarter, given by $\Delta g C r e d i t(-1)$; and change in the real gross domestic product growth in the previous quarter, given by $\triangle g G D P(-1)$. All regressions report $t$-statistics in brackets, based on standard errors clustered along the time and country dimensions. Also reported are the number of observations, adjusted $R$-square for the LSDV regression, type and total number of instruments used in each specification, $p$-values for the tests of the first and second order autocorrelations of the residuals $[A R(1)$ and $A R(2)]$, and Hansen test for the overidentification conditions. See Table A.1 for variable definitions.

\begin{tabular}{|c|c|c|c|c|c|c|c|c|}
\hline & \multicolumn{8}{|c|}{ Dependent variable: Equity fund flows } \\
\hline & \multicolumn{6}{|c|}{ All aggregate equity fund flows } & \multicolumn{2}{|c|}{$\begin{array}{l}\text { Fund flows with foreign } \\
\text { investment focus }\end{array}$} \\
\hline & $\begin{array}{c}\text { LSDV } \\
(1)\end{array}$ & $\begin{array}{c}\text { DGMM1 } \\
(2)\end{array}$ & $\begin{array}{c}\text { DGMM2 } \\
(3)\end{array}$ & $\begin{array}{c}\text { SGMM1 } \\
(4)\end{array}$ & $\begin{array}{c}\text { SGMM2 } \\
(5) \\
\end{array}$ & $\begin{array}{c}\text { DGMM3 } \\
(6) \\
\end{array}$ & $\begin{array}{c}\text { DGMM4 } \\
(7) \\
\end{array}$ & $\begin{array}{c}\text { SGMM3 } \\
(8) \\
\end{array}$ \\
\hline$\Delta S R$ & -4.481 & -9.520 & -9.534 & -10.481 & -10.483 & -9.101 & -11.056 & -12.283 \\
\hline & {$[-1.89]$} & {$[-3.07]$} & {$[-3.19]$} & {$[-4.60]$} & {$[-4.66]$} & {$[-2.99]$} & {$[-2.68]$} & {$[-4.16]$} \\
\hline FundFlow $(-1)$ & 0.339 & 0.294 & 0.316 & 0.315 & 0.328 & 0.307 & 0.391 & 0.416 \\
\hline & {$[4.06]$} & {$[1.27]$} & {$[1.04]$} & {$[1.61]$} & {$[1.30]$} & {$[1.26]$} & {$[1.68]$} & {$[2.29]$} \\
\hline$M K T(-1)$ & -0.050 & -0.036 & -0.045 & -0.040 & -0.045 & -0.035 & -0.028 & -0.031 \\
\hline & {$[-1.49]$} & {$[-0.92]$} & {$[-0.99]$} & {$[-1.02]$} & {$[-1.04]$} & {$[-0.94]$} & {$[-0.67]$} & {$[-0.76]$} \\
\hline$\Delta$ Output Gap $(-1)$ & & & & & & $\begin{array}{l}-2.048 \\
{[-0.49]}\end{array}$ & & \\
\hline$\Delta \Delta V A T(-1)$ & & & & & & $\begin{array}{l}-0.174 \\
{[-0.73]}\end{array}$ & & \\
\hline$\Delta g$ Credit $(-1)$ & & & & & & $\begin{array}{r}{[-0.1068} \\
0.068 \\
{[0.48}\end{array}$ & & \\
\hline$\Delta g G D P(-1)$ & & & & & & $\begin{array}{l}0.534 \\
{[1.30]}\end{array}$ & & \\
\hline $\begin{array}{l}\text { Number of } \\
\text { observations }\end{array}$ & 254 & 246 & 246 & 254 & 254 & 246 & 240 & 248 \\
\hline $\begin{array}{l}\text { Adjusted } R^{2} \\
\text { Instruments }\end{array}$ & 0.302 & & & & & & & \\
\hline$\Delta S R$ & & Lags $1-2$ & Lags 1-2 & Lags 1-2 & Lags 1-2 & Lags 1-2 & Lags 1-2 & Lags 1-2 \\
\hline FundFlow & & Lags $2-3$ & Lags $2-6$ & Lags $2-3$ & Lags 2-6 & Lags $2-3$ & Lags $2-3$ & Lags 2-3 \\
\hline$M K T$ & & Lags 2-3 & Lags $2-3$ & Lags 2-3 & Lags $2-3$ & Lags $2-3$ & Lags 2-3 & Lags 2-3 \\
\hline$\Delta$ Output Gap & & & & & & Lags $2-3$ & & \\
\hline$\Delta \Delta V A T$ & & & & & & Lag 1 & & \\
\hline$\Delta g C r e d i t$ & & & & & & $\operatorname{Lag} 1$ & & \\
\hline$\Delta g G D P$ & & & & & & Lag 1 & & \\
\hline Number of instr. & & 6 & 9 & 9 & 12 & 11 & 6 & 9 \\
\hline$A R(1)$ & & 0.052 & 0.087 & 0.033 & 0.056 & 0.056 & 0.056 & 0.033 \\
\hline$A R(2)$ & & 0.486 & 0.500 & 0.448 & 0.462 & 0.487 & 0.439 & 0.411 \\
\hline Hansen test & & 0.318 & 0.555 & 0.170 & 0.798 & 1.000 & 0.779 & 0.844 \\
\hline
\end{tabular}


Table 4

Money market fund flows and real rate changes

The quarterly country aggregate net inflows into money market funds domiciled and marketed in Austria, Finland, France, Germany, Italy, the Netherlands, Portugal, and Spain over the period 2003/q1-2010/q4 are regressed on changes in the local real short rate in each country $(\Delta S R)$. To eliminate the need for time fixed effects, all variables are expressed as deviations from their cross-sectional means. Column 1 provides the estimate using the least square dummy variable (LSDV) regression. Columns 2-3 and 4-5, respectively, provide the estimates using the difference generalized method of moments (DGMM) and system generalized method of moments (SGMM). Columns 6 and 7 use the same setup as Columns 2 and 4 but include four additional regressors: $\triangle$ Output Gap, $\Delta \Delta V A T, \Delta g C r e d i t$, and $\Delta g G D P$. The regressors are changes in the short-term real interest rate $\Delta S R$; fund flows at lag 1 , given by FundFlow $(-1)$; the country stock market return in the previous quarter $M K T(-1)$; changes in output gap in the previous quarter, given by $\Delta$ Output Gap $(-1)$; first difference of the change in the value added tax (VAT) rate in the previous quarter, denoted by $\Delta \Delta V A T(-1)$; change in the growth of total credit to private non-financial sectors in the previous quarter, given by $\Delta g C r e d i t(-1)$; and change in the real gross domestic product growth in the previous quarter, given by $\Delta g G D P(-1)$. All regressions report $t$-statistics in brackets, based on standard errors clustered along the time and country dimensions. Also reported are the number of observations, adjusted $R$-square for the LSDV regression, type and total number of instruments used in each specification, $p$-values for the tests of the first and second order autocorrelations of the residuals $[A R(1)$ and $A R(2)]$, and Hansen test for the overidentification conditions. See Table A.1 for variable definitions.

\begin{tabular}{|c|c|c|c|c|c|c|c|}
\hline & \multicolumn{7}{|c|}{ Dependent variable: Money market fund flows } \\
\hline & $\begin{array}{l}\text { LSDV } \\
(1)\end{array}$ & $\begin{array}{l}\text { DGMM1 } \\
(2) \\
\end{array}$ & $\begin{array}{c}\text { DGMM2 } \\
(3) \\
\end{array}$ & $\begin{array}{c}\text { SGMM1 } \\
(4)\end{array}$ & $\begin{array}{c}\text { SGMM2 } \\
(5) \\
\end{array}$ & $\begin{array}{c}\text { DGMM3 } \\
(6) \\
\end{array}$ & $\begin{array}{c}\text { SGMM3 } \\
(7) \\
\end{array}$ \\
\hline$\Delta S R$ & 7.655 & 8.375 & 7.665 & 10.939 & 10.549 & 9.518 & 10.964 \\
\hline FundFlow $(-1)$ & $\begin{array}{l}0.365 \\
{[4.94]}\end{array}$ & $\begin{array}{l}0.363 \\
{[6.13]}\end{array}$ & $\begin{array}{l}0.315 \\
{[3.89}\end{array}$ & $\begin{array}{l}0.382 \\
{[3.96}\end{array}$ & $\begin{array}{l}0.343 \\
{[3.33]}\end{array}$ & $\begin{array}{l}0.381 \\
{[5.05]}\end{array}$ & $\begin{array}{l}0.415 \\
{[3.88}\end{array}$ \\
\hline$M K T(-1)$ & $\begin{array}{l}0.062 \\
{[0.80]}\end{array}$ & $\begin{array}{l}-0.010 \\
{[-0.09]}\end{array}$ & $\begin{array}{l}-0.007 \\
{[-0.07]}\end{array}$ & $\begin{array}{l}0.028 \\
{[0.24]}\end{array}$ & $\begin{array}{l}0.030 \\
{[0.26]}\end{array}$ & $\begin{array}{l}-0.027 \\
{[-0.26]}\end{array}$ & $\begin{array}{l}0.017 \\
{[0.16]}\end{array}$ \\
\hline$\Delta$ Output Gap $(-1)$ & & & & & & $\begin{array}{l}8.047 \\
{[1.03]}\end{array}$ & $\begin{array}{l}8.214 \\
{[1.59]}\end{array}$ \\
\hline$\Delta \Delta V A T(-1)$ & & & & & & $\begin{array}{l}0.900 \\
{[1.46]}\end{array}$ & $\begin{array}{l}0.846 \\
{[1.32]}\end{array}$ \\
\hline$\Delta g$ Credit $(-1)$ & & & & & & $\begin{array}{l}-0.161 \\
{[-0.83]}\end{array}$ & $\begin{array}{l}-0.207 \\
{[-0.88]}\end{array}$ \\
\hline$\Delta g G D P(-1)$ & & & & & & $\begin{array}{l}-1.350 \\
{[-1.48]}\end{array}$ & $\begin{array}{l}-1.417 \\
{[-1.67]}\end{array}$ \\
\hline $\begin{array}{l}\text { Number of } \\
\text { observations }\end{array}$ & 249 & 240 & 240 & 249 & 249 & 240 & 249 \\
\hline $\begin{array}{l}\text { Adjusted } R^{2} \\
\text { Instruments }\end{array}$ & 0.231 & & & & & & \\
\hline$\Delta S R$ & & Lags 1-2 & Lags 1-2 & Lags $1-2$ & Lags $1-2$ & Lags $1-2$ & Lags $1-2$ \\
\hline FundFlow & & Lags 2-3 & Lags 2-6 & Lags $2-3$ & Lags 2-6 & Lags $2-3$ & Lags $2-3$ \\
\hline$M K T$ & & Lags $2-3$ & Lags $2-3$ & Lags $2-3$ & Lags $2-3$ & Lags $2-3$ & Lags $2-3$ \\
\hline$\Delta$ Output Gap & & & & & & Lags $2-3$ & Lags $2-3$ \\
\hline$\Delta \Delta V A T$ & & & & & & Lag 1 & Lag 1 \\
\hline$\Delta g C r e d i t$ & & & & & & $\operatorname{Lag} 1$ & Lag 1 \\
\hline$\triangle g G D P$ & & & & & & Lag 1 & Lag 1 \\
\hline Number of instr. & & 6 & 9 & 9 & 12 & 11 & 15 \\
\hline$A R(1)$ & & 0.011 & 0.011 & 0.010 & 0.011 & 0.013 & 0.011 \\
\hline$A R(2)$ & & 0.820 & 0.893 & 0.947 & 0.993 & 0.931 & 0.939 \\
\hline Hansen test & & 0.953 & 0.717 & 0.963 & 0.863 & 0.907 & 1.000 \\
\hline
\end{tabular}


Table 5

Equity fund flows and expected real rate changes

Similar to Table 3, we estimate the quarterly country aggregate net inflows into equity funds, where the actual real short rate changes are replaced with the expected real short rate changes $[\Delta S R($ expected $)]$, based on quarterly expected inflation rates derived from the European Commission's Consumer Survey data. All other variable definitions are the same as those in Table 3.

\begin{tabular}{|c|c|c|c|c|c|c|c|c|}
\hline & \multicolumn{8}{|c|}{ Dependent variable: Equity fund flows } \\
\hline & \multicolumn{6}{|c|}{ All aggregate equity flows } & \multicolumn{2}{|c|}{$\begin{array}{l}\text { Fund flows with foreign } \\
\text { investment focus }\end{array}$} \\
\hline & $\begin{array}{l}\text { LSDV } \\
(1)\end{array}$ & $\begin{array}{l}\text { DGMM1 } \\
(2) \\
\end{array}$ & $\begin{array}{c}\text { DGMM2 } \\
(3) \\
\end{array}$ & $\begin{array}{l}\text { SGMM1 } \\
(4)\end{array}$ & $\begin{array}{c}\text { SGMM2 } \\
(5)\end{array}$ & $\begin{array}{c}\text { DGMM3 } \\
(6) \\
\end{array}$ & $\begin{array}{c}\text { DGMM4 } \\
(7) \\
\end{array}$ & $\begin{array}{c}\text { SGMM3 } \\
(8) \\
\end{array}$ \\
\hline$\Delta S R($ expected $)$ & $\begin{array}{l}-5.251 \\
{[-1.83]}\end{array}$ & $\begin{array}{r}-12.171 \\
{[-3.47]}\end{array}$ & $\begin{array}{r}-12.041 \\
{[-3.53]}\end{array}$ & $\begin{array}{r}-12.324 \\
{[-4.05]}\end{array}$ & $\begin{array}{r}-12.262 \\
{[-4.11]}\end{array}$ & $\begin{array}{r}-11.700 \\
{[-3.32]}\end{array}$ & $\begin{array}{r}-13.990 \\
{[-2.80]}\end{array}$ & $\begin{array}{r}-14.623 \\
{[-3.38]}\end{array}$ \\
\hline FundFlow $(-1)$ & $\begin{array}{l}0.341 \\
{[4.07]}\end{array}$ & $\begin{array}{l}0.308 \\
{[1.31]}\end{array}$ & $\begin{array}{l}0.325 \\
{[1.05]}\end{array}$ & $\begin{array}{l}0.326 \\
{[1.63]}\end{array}$ & $\begin{array}{l}0.336 \\
{[1.29]}\end{array}$ & $\begin{array}{l}0.322 \\
{[1.32]}\end{array}$ & $\begin{array}{l}0.398 \\
{[1.76]}\end{array}$ & $\begin{array}{l}0.427 \\
{[2.40]}\end{array}$ \\
\hline$M K T(-1)$ & $\begin{array}{l}-0.049 \\
{[-1.46]}\end{array}$ & $\begin{array}{l}-0.032 \\
{[-0.81]}\end{array}$ & $\begin{array}{l}-0.040 \\
{[-0.85]}\end{array}$ & $\begin{array}{l}-0.036 \\
{[-0.93]}\end{array}$ & $\begin{array}{l}-0.041 \\
{[-0.92]}\end{array}$ & $\begin{array}{l}-0.032 \\
{[-0.83]}\end{array}$ & $\begin{array}{l}-0.027 \\
{[-0.69]}\end{array}$ & $\begin{array}{l}-0.038 \\
{[-1.12]}\end{array}$ \\
\hline$\Delta$ Output Gap $(-1)$ & & & & & & $\begin{array}{l}-1.984 \\
{[-0.46]}\end{array}$ & & \\
\hline$\Delta \Delta V A T(-1)$ & & & & & & $\begin{array}{l}-0.173 \\
{[-0.72]}\end{array}$ & & \\
\hline$\Delta g$ Credit $(-1)$ & & & & & & $\begin{array}{l}0.087 \\
{[0.63]}\end{array}$ & & \\
\hline$\Delta g G D P(-1)$ & & & & & & $\begin{array}{l}0.530 \\
{[1.21]}\end{array}$ & & \\
\hline $\begin{array}{l}\text { Number of } \\
\text { observations }\end{array}$ & 254 & 246 & 246 & 254 & 254 & 246 & 240 & 248 \\
\hline $\begin{array}{l}\text { Adjusted } R^{2} \\
\text { Instruments }\end{array}$ & 0.302 & & & & & & & \\
\hline$\Delta S R($ expected $)$ & & Lags 1-2 & Lags 1-2 & Lags $1-2$ & Lags 1-2 & Lags 1-2 & Lags 1-2 & Lags 1-2 \\
\hline FundFlow & & Lags 2-3 & Lags 2-6 & Lags 2-3 & Lags 2-6 & Lags 2-3 & Lags 2-3 & Lags 2-3 \\
\hline$M K T$ & & Lags 2-3 & Lags 2-3 & Lags 2-3 & Lags 2-3 & Lags 2-3 & Lags 2-3 & Lags 2-3 \\
\hline$\Delta$ Output Gap & & & & & & Lags $2-3$ & & \\
\hline$\Delta \Delta V A T$ & & & & & & Lag 1 & & \\
\hline$\Delta g C r e d i t$ & & & & & & Lag 1 & & \\
\hline$\Delta g G D P$ & & & & & & Lag 1 & & \\
\hline Number of instr. & & 6 & 9 & 9 & 12 & 11 & 6 & 9 \\
\hline$A R(1)$ & & 0.047 & 0.082 & 0.032 & 0.055 & 0.048 & 0.052 & 0.033 \\
\hline$A R(2)$ & & 0.396 & 0.416 & 0.359 & 0.379 & 0.391 & 0.393 & 0.382 \\
\hline Hansen test & & 0.308 & 0.482 & 0.481 & 0.221 & 1.000 & 0.957 & 0.971 \\
\hline
\end{tabular}


Table 6

Money market fund flows and expected real rate changes

Similar to Table 4, in this table we estimate the quarterly country aggregate net inflows into equity funds, where the actual real short rate changes are replaced with the expected real short rate changes $[\Delta S R$ (expected)], based on quarterly expected inflation rates derived from the European Commission's Consumer Survey data. All other variable definitions are the same as those in Table 4 .

\begin{tabular}{|c|c|c|c|c|c|c|c|}
\hline & \multicolumn{7}{|c|}{ Dependent variable: Money market fund flows } \\
\hline & $\begin{array}{l}\text { LSDV } \\
(1)\end{array}$ & $\begin{array}{c}\text { DGMM1 } \\
(2)\end{array}$ & $\begin{array}{c}\text { DGMM2 } \\
(3)\end{array}$ & $\begin{array}{c}\text { SGMM1 } \\
(4)\end{array}$ & $\begin{array}{c}\text { SGMM2 } \\
(5) \\
\end{array}$ & $\begin{array}{c}\text { DGMM3 } \\
(6) \\
\end{array}$ & $\begin{array}{c}\text { SGMM3 } \\
(7) \\
\end{array}$ \\
\hline$\Delta S R($ expected $)$ & $\begin{array}{l}9.695 \\
{[2.13]}\end{array}$ & $\begin{array}{r}13.318 \\
{[2.03]}\end{array}$ & $\begin{array}{r}12.492 \\
{[1.93]}\end{array}$ & $\begin{array}{r}14.695 \\
{[2.33]}\end{array}$ & $\begin{array}{r}14.279 \\
{[2.34]}\end{array}$ & $\begin{array}{r}14.452 \\
{[2.02]}\end{array}$ & $\begin{array}{r}15.066 \\
{[2.63]}\end{array}$ \\
\hline FundFlow $(-1)$ & $\begin{array}{l}0.366 \\
{[4.95]}\end{array}$ & $\begin{array}{l}0.367 \\
{[5.36]}\end{array}$ & $\begin{array}{l}0.319 \\
{[3.70]}\end{array}$ & $\begin{array}{l}0.388 \\
{[3.85]}\end{array}$ & $\begin{array}{l}0.348 \\
{[3.26]}\end{array}$ & $\begin{array}{l}0.387 \\
{[4.67]}\end{array}$ & $\begin{array}{l}0.422 \\
{[3.81]}\end{array}$ \\
\hline$M K T(-1)$ & $\begin{array}{l}0.059 \\
{[0.76]}\end{array}$ & $\begin{array}{l}-0.019 \\
{[-0.17]}\end{array}$ & $\begin{array}{l}-0.016 \\
{[-0.14]}\end{array}$ & $\begin{array}{l}0.021 \\
{[0.18]}\end{array}$ & $\begin{array}{l}0.023 \\
{[0.20]}\end{array}$ & $\begin{array}{l}-0.035 \\
{[-0.33]}\end{array}$ & $\begin{array}{l}0.010 \\
{[0.09]}\end{array}$ \\
\hline$\Delta$ Output Gap $(-1)$ & & & & & & $\begin{array}{l}8.001 \\
{[0.99]}\end{array}$ & $\begin{array}{l}8.155 \\
{[1.54]}\end{array}$ \\
\hline$\Delta \Delta V A T(-1)$ & & & & & & $\begin{array}{l}0.911 \\
{[1.48]}\end{array}$ & $\begin{array}{l}0.852 \\
{[1.35]}\end{array}$ \\
\hline$\Delta g$ Credit $(-1)$ & & & & & & $\begin{array}{l}-0.177 \\
{[-0.90]}\end{array}$ & $\begin{array}{l}-0.226 \\
{[-0.97]}\end{array}$ \\
\hline$\triangle g G D P(-1)$ & & & & & & $\begin{array}{l}-1.358 \\
{[-1.44]}\end{array}$ & $\begin{array}{l}-1.436 \\
{[-1.63]}\end{array}$ \\
\hline $\begin{array}{l}\text { Number of } \\
\text { observations }\end{array}$ & 249 & 240 & 240 & 249 & 249 & 240 & 249 \\
\hline $\begin{array}{l}\text { Adjusted } R^{2} \\
\text { Instruments }\end{array}$ & 0.231 & & & & & & \\
\hline$\Delta S R($ expected $)$ & & Lags $1-2$ & Lags 1-2 & Lags $1-2$ & Lags $1-2$ & Lags $1-2$ & Lags $1-2$ \\
\hline FundFlow & & Lags 2-3 & Lags $2-6$ & Lags $2-3$ & Lags $2-6$ & Lags $2-3$ & Lags $2-3$ \\
\hline$M K T$ & & Lags 2-3 & Lags $2-3$ & Lags $2-3$ & Lags $2-3$ & Lags $2-3$ & Lags $2-3$ \\
\hline$\Delta$ Output Gap & & & & & & Lags 2-3 & Lags $2-3$ \\
\hline$\Delta \Delta V A T$ & & & & & & Lag 1 & Lag 1 \\
\hline$\Delta g C r e d i t$ & & & & & & Lag 1 & Lag 1 \\
\hline$\Delta g G D P$ & & & & & & Lag 1 & Lag 1 \\
\hline Number of instr. & & 6 & 9 & 9 & 12 & 11 & 15 \\
\hline$A R(1)$ & & 0.011 & 0.011 & 0.011 & 0.011 & 0.013 & 0.011 \\
\hline$A R(2)$ & & 0.825 & 0.896 & 0.947 & 0.993 & 0.941 & 0.930 \\
\hline Hansen test & & 0.772 & 0.741 & 0.965 & 0.849 & 0.923 & 1.000 \\
\hline
\end{tabular}


Table 7

Robustness

We repeat the fund flow regression in Tables 3 and 4, Columns 2 and 4, for a precrisis subsample from 2003/q1-2007/q2 in Panel A, for a quarterly change in Taylor rule residuals $(\Delta T R)$ instead of the change in the real short rate $(\Delta S R)$ in Panel $\mathrm{B}$, and for a subsample of countries without Italy, Portugal, and Spain in Panel C. The Taylor rule residuals (for each country) follow from a pooled constrained ordinary least square regression of the nominal rate change $(E O N I A)$ on local inflation and gross domestic product growth for all countries. Columns 1-2 and 3-4, respectively, report the regressions for the net aggregate equity flows and money market flows.

\begin{tabular}{|c|c|c|c|c|}
\hline & \multicolumn{4}{|c|}{ Dependent variable: Fund flows } \\
\hline & \multicolumn{2}{|c|}{ Equity funds } & \multicolumn{2}{|c|}{ Money market funds } \\
\hline & $\begin{array}{c}\text { DGMM } \\
(1) \\
\end{array}$ & $\begin{array}{c}\text { SGMM } \\
(2) \\
\end{array}$ & $\begin{array}{c}\text { DGMM } \\
(3) \\
\end{array}$ & $\begin{array}{c}\text { SGMM } \\
(4)\end{array}$ \\
\hline \multicolumn{5}{|c|}{ Panel A: Subperiod analysis (2003/q1-2007/q2) } \\
\hline \multirow[t]{2}{*}{$\Delta S R$} & -11.021 & -10.887 & 9.788 & 12.376 \\
\hline & {$[-2.00]$} & {$[-2.11]$} & {$[0.93]$} & {$[1.61]$} \\
\hline \multirow[t]{2}{*}{ FundFlow $(-1)$} & 0.065 & 0.191 & 0.291 & 0.389 \\
\hline & {$[0.49]$} & {$[1.30]$} & {$[1.68]$} & {$[1.76]$} \\
\hline \multirow[t]{2}{*}{$M K T(-1)$} & -0.043 & -0.053 & 0.013 & 0.159 \\
\hline & {$[-0.70]$} & {$[-0.83]$} & {$[0.07]$} & {$[0.79]$} \\
\hline $\begin{array}{l}\text { Number of } \\
\text { observations }\end{array}$ & 134 & 142 & 128 & 137 \\
\hline \multicolumn{5}{|c|}{ Panel B: Taylor rule residuals as alternative policy proxy } \\
\hline \multirow[t]{2}{*}{$\Delta T R$} & -13.900 & -15.082 & 12.279 & 16.194 \\
\hline & {$[-2.75]$} & {$[-4.08]$} & {$[1.37]$} & {$[2.07]$} \\
\hline \multirow{2}{*}{ FundFlow $(-1)$} & 0.295 & 0.316 & 0.364 & 0.384 \\
\hline & {$[1.25]$} & {$[1.59]$} & {$[6.22]$} & [3.99] \\
\hline \multirow{2}{*}{$M K T(-1)$} & -0.023 & -0.034 & -0.014 & 0.015 \\
\hline & {$[-0.47]$} & {$[-0.83]$} & {$[-0.12]$} & {$[0.13]$} \\
\hline $\begin{array}{l}\text { Number of } \\
\text { observations }\end{array}$ & 240 & 248 & 235 & 244 \\
\hline \multicolumn{5}{|c|}{ Panel C: Subsample analysis (drop Italy, Portugal, and Spain) } \\
\hline \multirow[t]{2}{*}{$\Delta S R$} & -7.638 & -8.465 & 9.177 & 12.608 \\
\hline & {$[-2.92]$} & {$[-3.20]$} & {$[1.13]$} & {$[2.10]$} \\
\hline \multirow[t]{2}{*}{ FundFlow $(-1)$} & 0.193 & 0.225 & 0.336 & 0.348 \\
\hline & {$[0.93]$} & {$[1.32]$} & {$[2.60]$} & [2.39] \\
\hline \multirow[t]{2}{*}{$M K T(-1)$} & -0.011 & -0.013 & -0.031 & 0.008 \\
\hline & {$[-0.19]$} & {$[-0.29]$} & {$[-0.20]$} & {$[0.05]$} \\
\hline $\begin{array}{l}\text { Number of } \\
\text { observations }\end{array}$ & 154 & 159 & 145 & 154 \\
\hline
\end{tabular}


Table 8

Equity fund flows and fund excess returns simultaneously estimated

Eq. (1) relates equity fund flows (FundFlow) to lagged fund flows and the contemporaneous change in the short-term real interest rate $(\Delta S R)$ [or alternatively the change in the expected short-term real interest rate, $\Delta S R$ (expected), based on inflation expectations from consumer surveys] and is estimated (as before) using the difference generalized method of moments (DGMM) approach. Eq. (2) relates fund excess returns, FundReturn $-L F H I$ to contemporaneous $(\Delta S R)$ and lagged short-term real interest rate changes $[\Delta S R(-1)$ and $\Delta S R(-2)]$ with the cross-equation restriction implied by the estimated flow dynamics. Eq. (2) is estimated without differencing, uses the same instrument set as Eq. (1) and includes either no fixed effects or country fixed effects. To eliminate the need for time fixed effects, all variables are expressed as deviations from their cross-sectional means. The equity fund flow aggregates are based on all locally distributed and marketed equity funds in Austria, Finland, France, Germany, Italy, the Netherlands, Portugal, and Spain over the period 2003/q1-2010/q4. Columns 1-4 present results based on equal country weights (1/8). Columns 5-8 use country weights given by LocInstShare, defined as the proportion of the local stock market held by local institutional investors. Thus, each country $c$ has a regression weight of $\left[\right.$ LocInstShare $(c) / \sum_{c}$ LocInstShare $\left.(c)\right]$ each quarter. All regressions report robust $t$-statistics in brackets. Also reported are the number of observations and type and number of instruments.

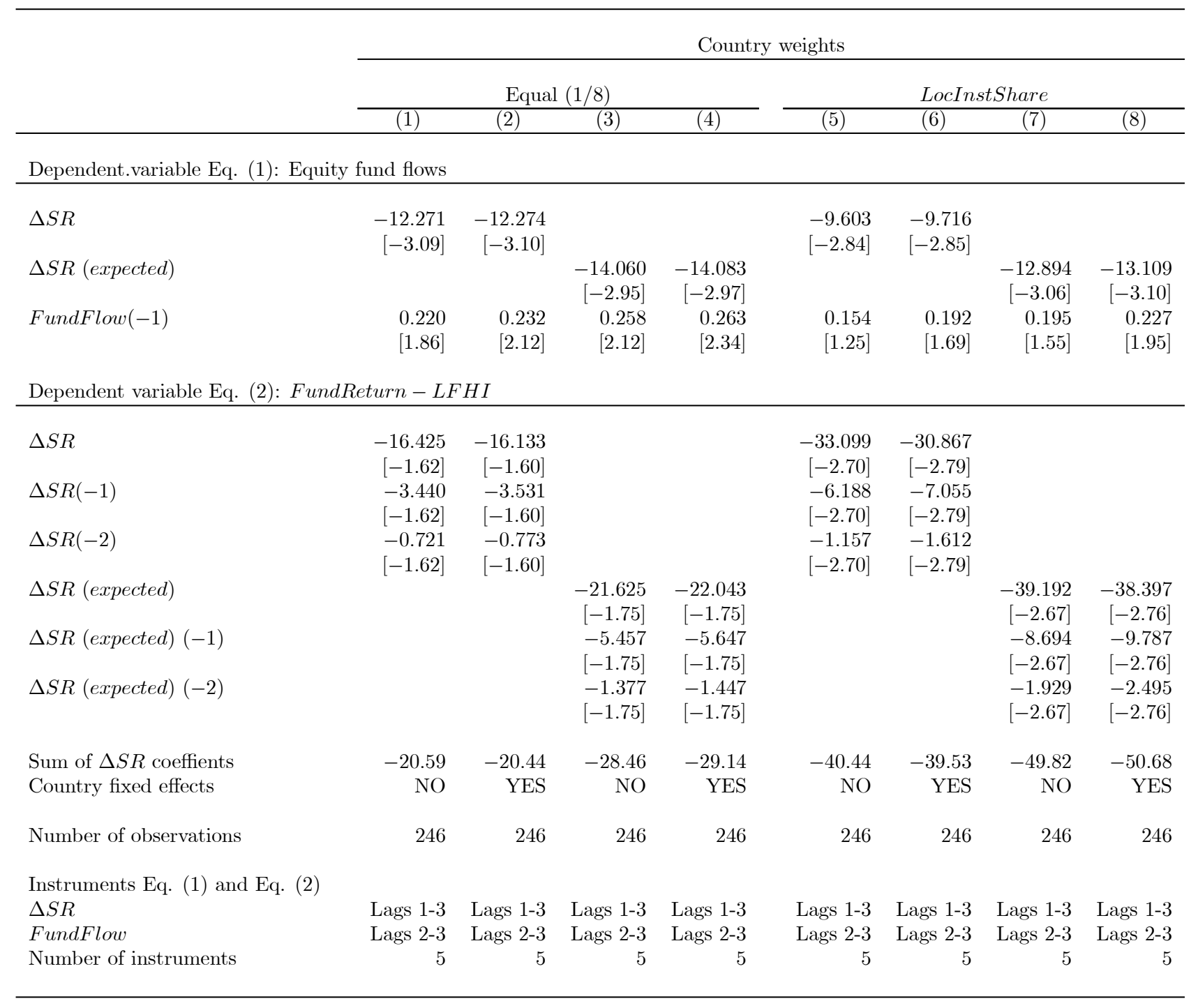




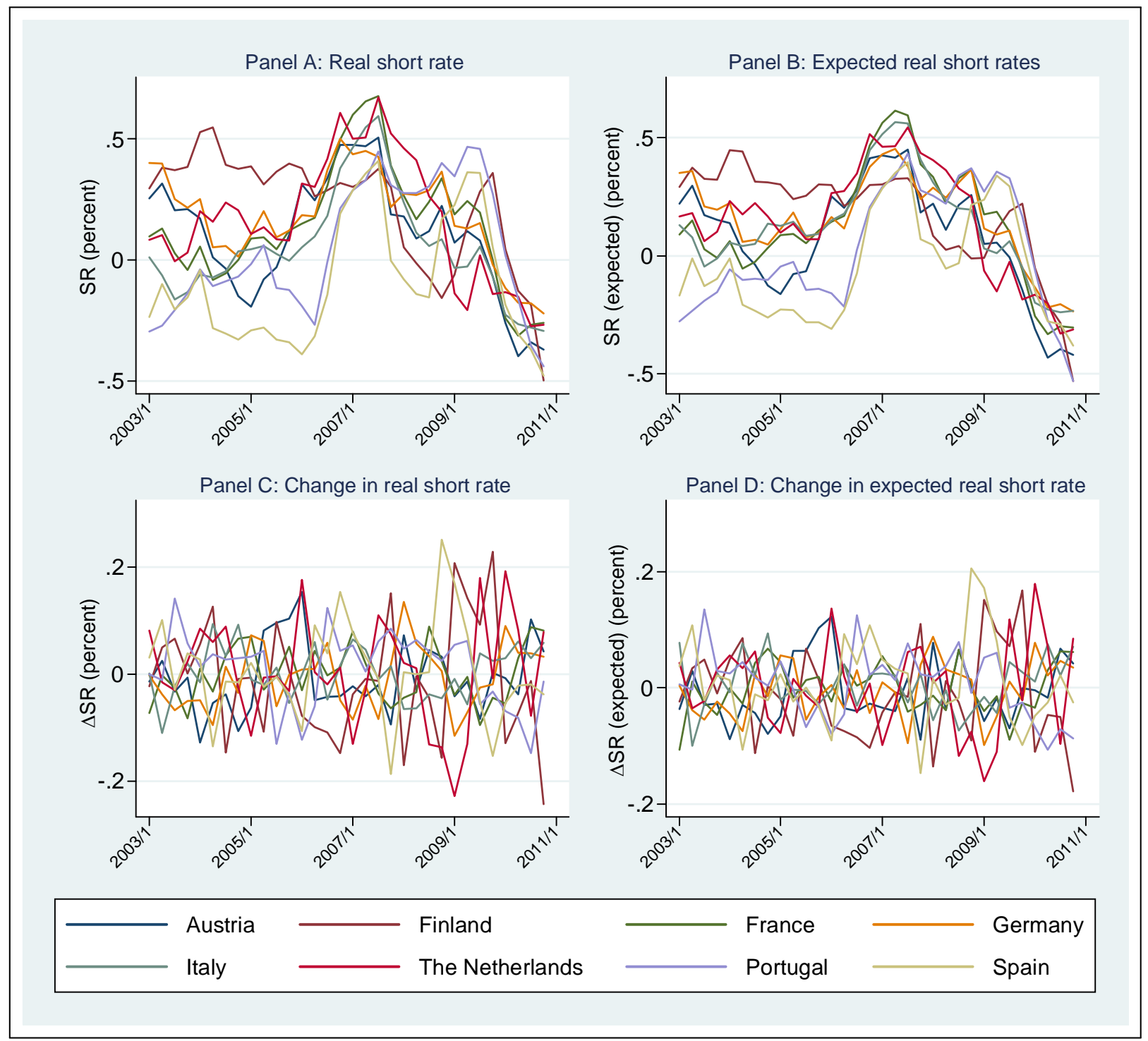

Figure 1: Cross-country variation of real monetary policy rates. Plotted in Panels A and B are the quarterly real short-term interest rate $(S R)$ and expected real short-term interest rate $[S R$ (expected)], respectively, for each of the eight eurozone countries Austria, Finland, France, Germany, Italy, the Netherlands, Portugal, and Spain in the period 2003/q1-2010/q4. Panels C and D plot the quarterly change of the real short rate $(\Delta S R)$ and the quarterly change of the expected real short rate [SR (expected)]. 


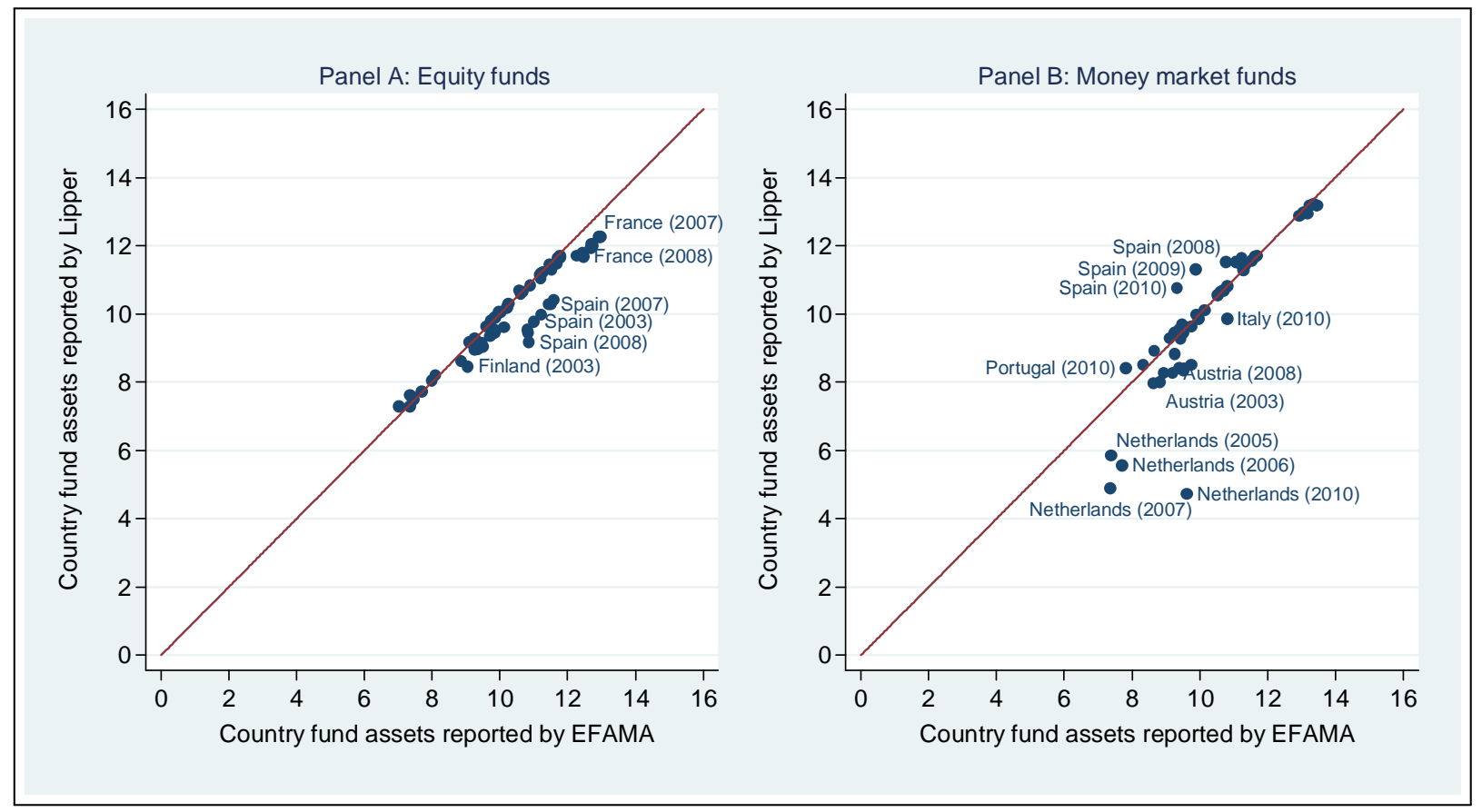

Figure 2: Total reported fund assset value by country and year (in log of million euros). We plot the total net fund asset value reported by the Lipper fund database on the y-axis against that reported by the European Fund and Asset Management Association (EFAMA) on the $\mathrm{x}$-axis for the eight eurozone countries Austria, Finland, France, Germany, Italy, the Netherlands, Portugal, and Spain from 2003 to 2010. Panel A represents the aggregate equity fund values; Panel B, the aggregate money market fund values. 


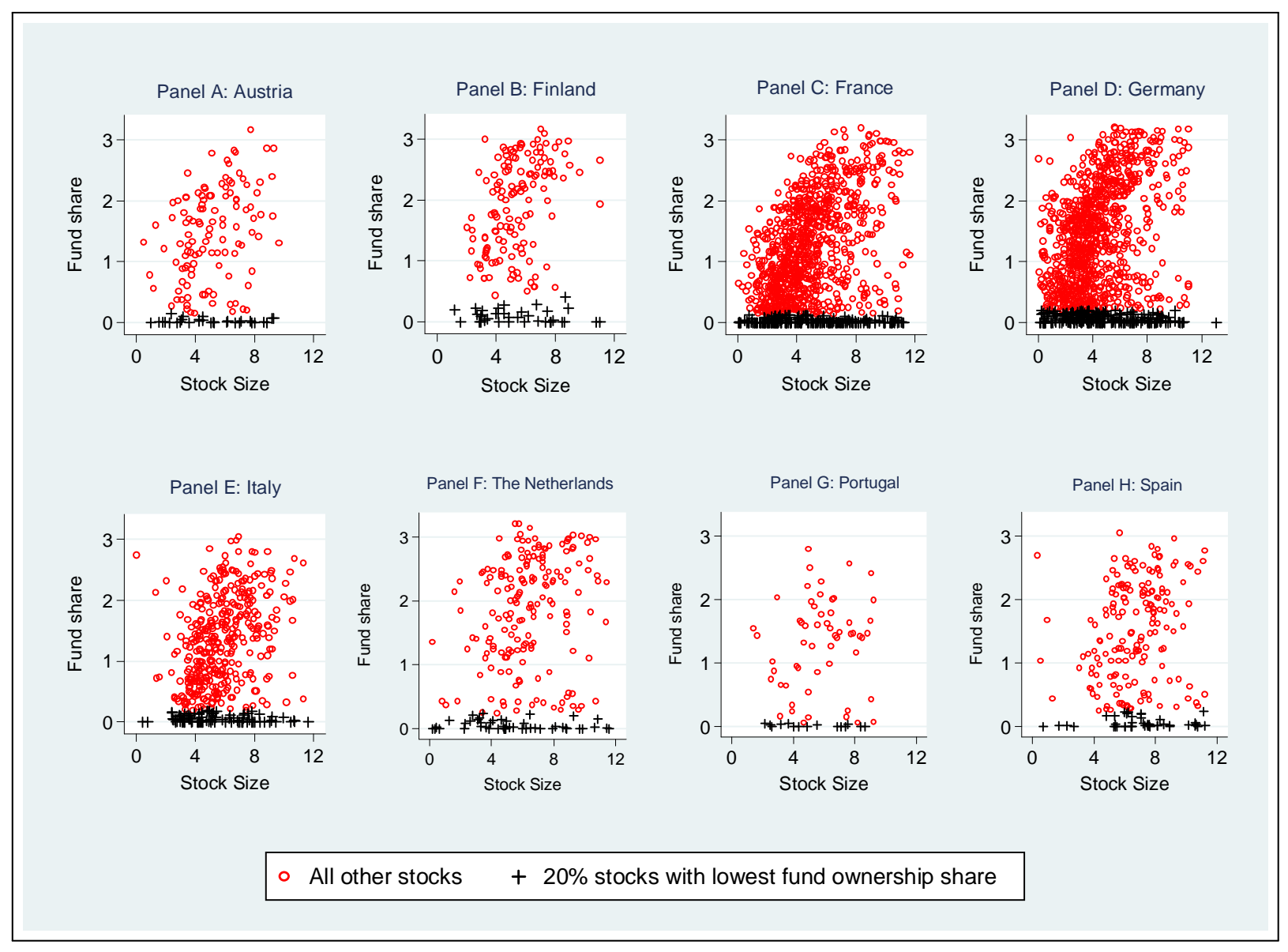

Figure 3: Stock size and fund ownership share. Plotted are the aggregate fund ownership share for stocks in eight eurozone countries (Austria, Finland, France, Germany, Italy, the Netherlands, Portugal, and Spain) against the stock size. The 20\% of stocks with the lowest fund ownership share in each country are marked by black crosses, and all other stocks are marked by red circles. We calculate the aggregate fund holdings for each stock as the natural logarithm of the aggregate euro holdings by all domestic equity funds relative to the stock's market capitalization value at the beginning of the period plus 1, averaged over the sample period 2003/q1-2010/q4. The x-axis represents the natural logarithm of the market capitalization value of the stock in million euros plus 1 , averaged over the sample period. 


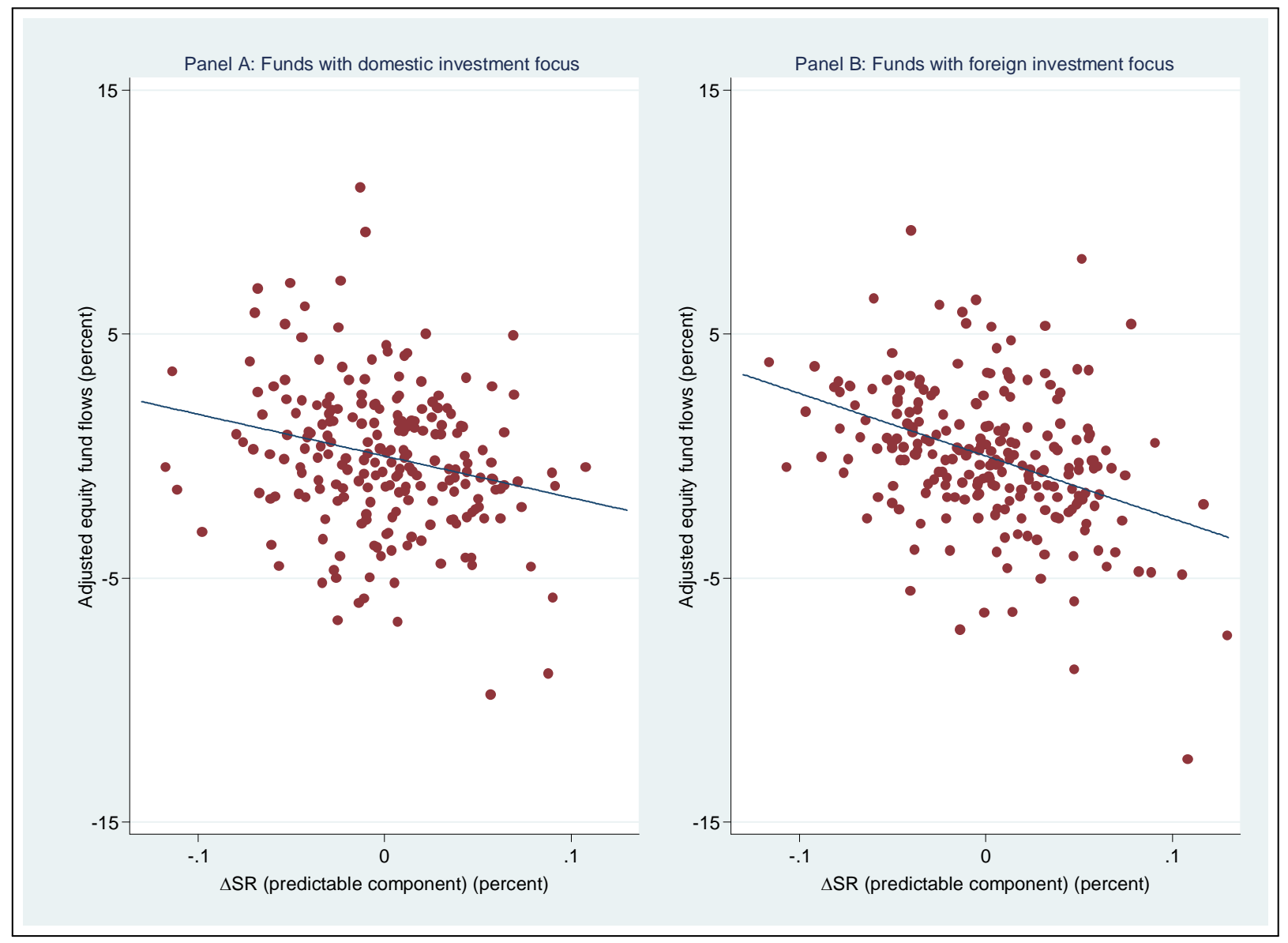

Figure 4: Equity fund flows and real short rate changes. The figure shows the quarterly adjusted equity fund flows (from 2003/q1 to 2010/q4) for the eight eurozone countries (Austria, Finland, France, Germany, Italy, the Netherlands, Portugal, and Spain) against the quarterly predicted change of their respective local real short-term interest rates $(\Delta S R)$. Panel A plots the flows for equity funds with a domestic investment focus; Panel B, for equity funds with a foreign investment focus. The adjusted equity fund flows denote the difference between the observed equity fund flows and the predictable component of fund flows from lagged fund flow $[$ FundFlow $(-1)]$ and lagged market return $[M K T(-1)]$. Fund flows are plotted on the y-axis and expressed in percent of assets under management. On the x-axis, we plot the predictable component of the local real short rate changes (in percent). The predictable component is the one spanned by the instrument set used in Table 3. Panel B is based on the estimates reported in Table 3, Column 7, and Panel A is plotted in a similar manner. 